\title{
A VENEZUELA NAS REFORMAS ESTRUTURAIS DO SISTEMA COLONIAL ESPANHOL.
}

MANUEL NUNES DIAS

Disciplina: História Americana

O mercantilismo tradicional espanhol, estruturado nas centrais de Sevilha e Cadiz e nos Consulados de Lima e México, foi defensivo e dissipador. Encegueirado pelo "bulionismo" cometeu o erro "crisohedonista" confundindo riqueza com metais preciosos.

A limitação do tráfico a apenas três empórios vitais na América - Veracruz em Nova Espanha, Cartagena em Nova Granada e Nombre de Dios, mais tarde Portobelo, no istmo do Panamá - congestionou o trânsito mercantil, ao mesmo tempo que facilitou a comercialização de produtos estrangeiros nas "escápulas" que o poder público deixava de vigiar, em virtude das distâncias geográficas e vulnerabilidade das rotas, animando o contrabando exercido por alienígenas e nacionais coniventes.

A Espanha era uma nação potencialmente rica, mas que perdia oportunidades de utilização efetiva de suas riquezas e marcava passo na retaguarda do capitalismo europeu. A obsessão pelo "político" gerava malefícios no "econômico". A forma de pagamento das importações procedentes do exterior era representada pelas carregações coloniais, inconvenientes dum sistema de exploração que se revelou nocivo à economia do reino e do império. O prestígio no continente europeu era anseio do trono. Por isso a monarquia centralizada nunca conseguiu demover a ação dos atravessadores. A Coroa defrontou-se sempre com crise crônica de capitais. A mantença do giro transoceânico fazia-se à custa de vultosos recursos de financiamento, de outorgas, de isenções fiscais, de certos privilégios e doutros fatores que se refletiam nas receitas públicas.

O reino não tinha muito o que exportar, alem do que extraia de seu patrimônio ultramarino. O decrescente volume e valor dos gèneros coloniais acarretava retração do crédito no estrangeiro, expedien- 
te imprescindivel para a importação do essencialíssimo para o custeio do tráfico americano. A Coroa mantinha sua soberania à custa duma dispendiosa mobilização burocrática - civil e militar - que se revelava na fuga do metal precioso para o exterior. A política era de transporte, não de fixação, dano comprovado pela não ancoragem do ouro e da prata procedentes do ultramar. A Espanha figurava na urdidura do tráfico americano como simples intermediária entre as regiões coloniais e a Europa capitalista. O lucro estava no trânsito de produtos formados e consumidos fora do reino. As carregações de torna-viagem chegavam à Península de passagem, sem conseguirem ancorar, dada a anemia do mercado interno.

Semelhante sistema colonial dos Habsburgos fundamentava-se no monopólio e na centralização, ideal mercantilista que se revelou improfícuo e lesivo à economia espanhola. O protecionismo excessivo, que se exprimia no aumento da tributação e encarecimento dos gêneros, favorecia a concorrência dos produtos estrangeiros e, em vista disso, o comércio ilícito. Ademais, o sistema era apenas oportuno à monarquia centralizada e a um pequeno grupo aninhado no alto comércio gaditano.

Interesses pessoais e setoriais influiam na formulação e aplicação da política econômico-financeira. O sistema colonial havia sido idealizado pelas matrizes de Sevilha e Cadiz, a cavaleiras do trono, sem qualquer consulta às conveniências nacionais. A falta de visão de alguns reduzidos grupos empresariais e a obsessão da Coroa pela salvaguarda da monarquia centralizada intensificaram, em termos dramáticos, a estatização da economia.

O regime do porto único para o tráfico americano era um embaraço ao fomento da Espanha Mediterrânea e do Cantábrico. $\mathrm{O}$ exclusivismo era fator de operações sub-reptícias ao longo dos três mil quilômetros do linhol marítimo do reino e nas costas do Pacífico e do Atlântico americanos, notadamente nos espaços distanciados e pouco vigiados.

A medida, porem, que a Espanha começou a ocupar os vazios interregionais e a integrar suas áreas no mesmo rítmo criador, a Coroa foi levada a alterar o sistema colonial até então vigente. O predomínio da faixa centro-sul do reino procuraria neutralizar o despertar da orla periférica, sobretudo do País Basco e da Catalunha, que acabariam por reclamar sua participação direta no tráfico americano, sem os entraves "del puerto único", conforme já o notou Valentín Vázquez de Prada (1).

(1). - Cf. Las rutas comerciales entre España y America en el Siglo XVIII, in "Anuário de Estudios Americanos", XXV, págs. 197 e segs. Sevilha, 1968 . 
O contrabando havia demonstrado as debilidades do monopólio gaditano. Ademais, a investida do mercantilismo estrangeiro contra a concretada barragem do tráfico americano era arma de enorme eficiência .

Guindados os Borbons ao trono de Espanha, deu-se um balanço à vida pública. Para a Coroa o que importava era a salvaguarda de sua soberania no reino e no ultramar. Carlos II, último representante do ramo primogênito da Casa d'Áustria, morrera em 1700 sem deixar sucessor. Por testamento havia legado a Coroa a Felipe d'Anjou, neto de Luis XIV que, efetivamente, depois da Guerra da Sucessão de Espanha, tomou posse do trono com o título de Felipe V. Pelo tratado de Utrecht, em 1713, o novo monarca foi reconhecido como legitimo sucessor, com a condição de que nunca as Coroas de França e Espanha viessem a reunir-se. Teve então início a nova dinastia que criou condições para implantar as reformas estruturais, adequando-as à realidade nacional.

Nessa linha de mudança do sistema colonial encontra-se a programação de Gerônimo de Uztáriz, conselheiro de Felipe V (2). Sua obra foi mais tarde, em 1740, reavivada por Bernardo de Ulhoa (3) integrante da equipe assessora do trono. Suas obras representam o renovo da primeira fase borbônica, apesar de não constituirem um corpo de doutrina em matéria de política econômica. Desempenharam, contudo, importante papel no processo de desenvolvimento do reformismo institucional, ao proporem o fomento de fábricas no reino e o revigoramento do comércio e da navegação.

A renovação dos quadros dirigentes da monarquia, com a ascenção dos Borbons, abriu um processo político que começou logo a interessar alguns setores e a preocupar as lideranças do alto comércio gaditano mais atentas para a significação e a profundidade que ele poderia assumir. Afinal, os Consulados de Sevilha e Cadiz, mais do que os portos do Mediterrâneo e do Cantábrico apequenados na asfixia de uma oposição sem maior ressonância nacional, mas que usufruira, até então, os favores da Coroa, teriam a oportunidade de enfrentar os problemas crônicos que derivavam do sistema colonial vigente.

Os quadros da política ultramarina estavam viciados por deformações notórias. Tratava-se de superar todas as restrições que ames-

(2). - Cf. Uztáriz (Gerônimo de), Teoria y Práctica del Comercio y de la Marina. Madrid, 1742; Mounier (Alfred), Les Faits et la Doctrine Economique en Espagne sous Philip V. Gerônimo de Uztáriz, 1670-1732 Paris, 1919. 1740 .

(3). - Restabelecimiento de las fabricas y comercio español. Madrid, 
quinhavam a atividade econômica da Espanha periférica com uma experiência que levaria a resultados surpreendentes. Renovar, a partir das bases, desde que fosse assegurado um mínimo da liberdade mercantil para uma renovação autêntica e não dirigida, iria significar uma estrutura inteiramente remodelada, com inevitáveis e profundas surpresas.

Do ponto de vista político, a renovação estava condicionada a duas preocupações essenciais. A primeira delas era a das crises latentes entre o trono que assumia o comando das reformas e os dirigentes tradicionais do tráfico colonial que teimavam em conservar os controles. As bases políticas montam-se a partir dos esquemas planejados pelos teóricos assessores da Coroa. Esta testou o seu prestígio e consolidou a sua autoridade. A estrutura que se iria forjar seria influenciada pela conjuntura internacional e pelas condições do reino e do império, a segunda marca do processo de renovação. Os portos marítimos pretendiam articular um movimento de amplitude nacional, visando a condicionar os processo de renovação dos quadros dirigentes do comércio americano, a uma alteração fundamental no seu programa e na sua tática.

A Espanha periférica tentaria assumir a responsabilidade de empunhar a bandeira social, dando consequência e organicidade a uma tendência da nova dinastia, o que, por sua vez, refleteria uma orientação pessoal de Carlos III e de seus assessores "ilustrados". Não era fácil, entretanto, vincular uma renovação de quadros a reformas de programas. Contudo, o sistema colonial passaria por uma reformulação de estruturas da maior profundidade e importância.

Os portos marítimos do reino já se mostravam em condições de reivindicar sua participação direta no tráfico americano, notadamente - País Basco e a Catalunha, sobretudo Barcelona, graças às suas manufaturas e ao giro de seu comércio (4).

O setor privado dos empórios do Mediterrâneo e do Cantábrico responderam aos estímulos que a Coroa colocou à sua dsposição para acelerar o intercâmbio mercantil. Chegara a hora de fazer-se funcionar as coisas em termos práticos. Já haviam instrumentos em número suficiente para que o comércio colonial iniciasse uma ação efetiva e chegasse a resultados concretos com o ressurgimento da economia. $\mathrm{O}$ esforço vinha sendo realizado mediante a aplicação de regras comuns

(4). - Cf. Smith (Robert Sidney), The Spanish Guild Merchant. A History of the Consulado, 1250-1700, págs. 140 e segs. Durham, North Carolina, 1940; Rahola (F.), Comercio de Cataluña com America en el siglo XVIII, págs. 36 e segs. Barcelona, 1931; Vilar (Pierre), La Catalogne dans l'Espagne moderne, t. I, págs. 672 e segs. Paris, 1962. 
de teoria econômica e Carlos III não omitiu neste processo a questão política.

Os capitais comerciais e industriais da Espanha periférica exigiam pronta saida de seus produtos para os entrepostos ultramarinos. A aliança do trono, através de seus conselheiros políticos e economistas, com a burguesia dos portos marítimos criaria condições propícias ao rompimento do exclusivismo gaditano. A atitude assumida pela realeza indica bem a orientação que se pretendia seguir na constituição daquilo que se pode considerar como uma nova experiência de exploração do tráfico americano.

Tal iniciativa visava, por um lado, infundir novo alento à navegação nacional espanhola e, por outro lado, fomentar a riqueza social . Diante da situação, a Coroa sentiu todas as implicações e, antes mesmo de "libertar" o tráfico colonial ou de estabelecer uma organização muito estruturada, ofereceu uma modalidade de cooperação flexivel e, sobretudo, prática, que com o tempo permitiria uma solução mais institucionalizada. Se os resultados alcançados o justificassem, a experiência permitiria cogitar de um avanço a passo mais largo.

O primeiro propósito dos assessores do trono consistia em solucionar duas questões vitais: o trânsito ilícito e o recobramento do tráfico que minguava a cada torna-viagem. Só mais tarde, depois disso resolvido, é que se superariam os entraves que impediam a burguesia periférica do reino e do ultramar de participar diretamente dos benefícios oriundos do comércio americano. Todos políticos e economistas "iluminados" estavam de acordo em restaurar a navegação comercial' entre Espanha e América. O que se procurava, afinal, era o meio adequado, que figurava na pauta das discussões dos teóricos, para excluir-se do mercado americano os artigos estrangeiros e favorecer tanto quanto fosse possivel o giro dos produtos do reino. Essa era a política mais condizente com os interesses da indústria e do comércio nacionais (5).

A orientação da Coroa tinha por objetivo mudar a imagem do sistema colonial, dando-lhe características típicas de eficiência empresarial, nos moldes da iniciativa privada aberta, tambem, às forças sócio-econômicas da linha portuária do Mediterrâneo e do Cantábrico.

Movimentos que já vinham se adensando, desde Felipe V, tomaram vulto no reinado de Carlos III para assumirem proporções maiores nos últimos anos de sua administração. A realeza forneceria as ferramentas institucionais necessárias para que o empresariado espahol conseguisse efetivamente a abertura do mercado internacional.

(5). - Prada (V. Vázquez de), art. cit., págs. 199 e segs. 
Este mercado, alem dos fatores qualidade, preços e pontualidade no atendimento dos pedidos, envolvia o aspecto tradição exportadora, que era o que faltava à Espanha. E essa tradição, elemento vital, só seria alcançada à medida em que o capitalismo espanhol incipiente se afirmasse no mercado externo.

A Coroa não era comerciante. Os reis espanhois nunca demonstraram possuir espírito de empresa. E quando pretenderam realizar negociações como únicos empresários coloniais cometeram loucuras. Assim, a solução encontrada foi a de mobilizar o empresariado privado, constituindo-se uma política flexivel e de incentivos fiscais. Apenas mobilizando a burguesia dos portos marítimos, em todas as frentes, poderia a monarquia centralizada enfrentar a guerra do comércio externo, fomentar a navegação colonial e o tráfico respectivo.

Alcançar semelhantes resultados, de que modo? Mediante o tradicional sistema de frotas e feiras? Instituindo Companhias? Ou estabelecendo o "Comércio Livre"? O que se impunha, no entender de Jerônimo de Uztariz, fiel representante dos teóricos da primeira metade do século XVIII (6), era o fomento industrial espanhol, único meio de se realizar o giro mercantil com gêneros produzidos no próprio reino e de se evitar a fuga de metal amoedado para o estrangeiro. Os resultados alcançados é que importavam. O industrial espanhol devia buscar o mercado internacional não no sentido de colocar as eventuais sobras de sua produção, mas criando, efetivamente, uma estrutura de vendas consentânea com as normas de comercialização. A Espanha deveria passar a ser não apenas um exportador de sobras, mas importador de faltas. O industrialismo nacional seria o resguardo do comércio americano. De nada adiantaria fazer-se o tráfico através de frotas e feiras, ou por meio de Companhias de Comércio e Navegação, ou através de qualquer outro expediente - entes de direito público ou de direito privado - se os gêneros não fossem "fabricados en el propio país" (7).

De há muito a Catalunha e o País Basco desejavam participar diretamente do tráfico americano. São conhecidos os anseios bilbainos e de Barcelona nesse sentido. Logo no começo do reinado de Felipe V, em 1701-1702, a Cortes da Catalunha solicitaram dos favores do trono dois navios para o comércio indiano registrados no porto da Barcelona. E nas Cortes de 1706 já desejavam quatro navios, sinal evidente do fomento da economia regional catalã. A Guerra da Sucessão da Espanha fez malograr tais aspirações, visto os catalães haverem tomado o partido do arquiduque Carlos, filho do imperador da pág. 110 .

(6). - Cf. Teoria y Práctica del Comercio y de la Marina, cit. ed. (7). - Ibidem. 
Austria, Leopoldo, que concorrera ao trono de Espanha com o neto de Luis XIV, Filipe d'Anjou - Filipe V (8).

De igual modo a burguesia do Cantábrico procurou os favores da Coroa para usufruir dos benefícios do tráfico legal americano, sem, contudo, consegui-lo nas primeiras petições endereçadas. As resistências "del Señorio de Vizcaya" fizeram frustrar as pretensões do comércio de Bilbao (9).

A Guerra da Sucessão da Espanha favoreceu sobremaneira a ação dos comissários volantes estrangeiros, sobretudo os britânicos, aquinhoados por certas concessões régias - o "asiento de negros" e o instituto "del navio de permiso" - através das quais conseguiram ampliar o tráfico ilícito graças à conivência de determinados oficiais do rei corrompidos pelas ofertas da "Compañia del Asiento" (10).

As primeiras décadas do século XVIII foram propícias ao contrabando estrangeiro na América espanhola. O capitalismo francobritânico foi o mais beneficiado. As doações e privilégios à Companhia "del Mar del Sur" foram instrumentos legais que possibilitaram o contrabando em larga escala pelo Rio da Prata - "eldorado" de navios ingleses - para o abastecimento de Buenos Aires, Paraguai, Chile e Perú, fato conhecido, embora ainda não apuradas as quantidades do volume e do valor de semelhante tráfico.

Devido à Guerra na Europa a América foi alvo das investidas dos atravessadores alienígenas. A Espanha mostrou-se incapaz de abastecer o mercado colonial por duas razões: devido ao conflito armado no continente e às vantagens de qualidade e preços oferecidas pelas mercadorias estrangeiras, sempre melhor recebidas pela clientela americana. Dir-se-ia que a América, ilhada do reino, abriu-se ao contrabando franco-inglês que passou a operar, desimpedido, nas terras e águas de ambas as costas do patrimônio de Filipe V - no Pacífico, no Atlântico e no "Mar del Sur" (11).

(8). - Cf. Rahola (F.), op. cit., pág. 36; Vilar (P.), op. cit., págs. 672 e seg; Prada (V. Vázquez de), art. cit., pág. 199.

(9) . - Cf. Guiard (T.), Historia del Consulado y Casa de Contratación de Bilbao y del comercio de la villa $(1514-1914)$, t. II, págs. 819 e segs. (10). - Vignola (L.), El asiento francés (1701-1713) e inglés (1713-1750), y el comercio franco-español desde 1700 a 1730, in "Anuario de Historía del Rerecho Español", t. V. 1928; Nelson (G.H.), Contraband Trade under the Asiento, 1730-1739, in "American History Review", t. 51, 1945.

(11) - Cf. Villalobos (Sergio R.), Contrabando francés en el Pacifico, 1700-1724, in "Revista de Hístoria de Ameríca", $\mathrm{n}^{\circ}$ 51, junho, págs. 37 e segs. México, 1961; Brown (Vera L.), The South Sea Company and the contraband trade, in "American Historical Rev" w", t. XXXI, págs. 622 e segs., 1926; Pantaleão (Olga), A penetração comercial da Inglaterra na América Espanhola (1713-1783, Sắo Paulo, 1946. 
Superados os problemas do conflito armado, Patiño - "Intendente de Marina y Presidente de la Casa de la Contratación", definitivamente estabelecida em Cadiz, - com plena competência e jurisdição em questões de navegação e comércio de Indias, passou a dirigir a elaboração e a execução das reformas estruturais.

A partir de então tudo começou a mudar. Foi um trabalho lento e dificil, tal a profundidade dos hábitos arraigados em quase todas as administrações anteriores e a sucessão de problemas que passaram, como cascata, de um governo para outro.

Entre as normas legais saneadoras do tráfico colonial figura o "Proyecto para Galeones y flotas del Peru, y Nueva España, y para navios de Registro y avisos, que navegaren a ambos Reynos" (12), que determinava que a frota de Nova Espanha partiria em $1 .^{\circ}$ de junho de cada ano, detendo-se apenas 6 dias, no máximo, em Puerto Rico para aguada, 15 dias em Veracruz para a feira e, na torna-viagem, só 15 dias em Havana, donde tomaria o rumo direto para Cadiz. A segunda frota, a chamada do Panamá - ou "Los Galeones" - sairia em $1 .^{\circ}$ de setembro de cada ano, ancorando até 50 dias em Cartagena e $60 \mathrm{em}$ Portobelo para a feira e, no regresso ao reino, pararia 30 dias em Cartagena e 15 em Havana. Admitiam-se ainda "navios de Registro y avisos" para as regiões americanas que não necessitassem de remessas regulares. Todos os navios deviam ser de construção nacional ficando proibida, daí em diante, a navegação para a América em navios "de Fábrica Extrangera" (13).

O "Proyecto para Galeones y flotas" - Ordenança de 4 de abril de 1720 - foi um instrumento legal decisivo para que se alcançassem certos resultados pretendidos. O programa de Filipe V, pelo inspirado realismo de suas definiçōes fundamentais, representou um compêndio de objetivos e providências que com sabedoria puderam convergir para a recuperação do comércio e da navegação. Claro que o "Proyecto" de 1720, embora contenha diretriz inovadora, acha-se ainda grandemente impregnado pelos ideais do mercantilismo tradicional do tempo dos Austrias. Mas dilucida-se nele a atitude assumida pela Coroa, realista e prática, indicando a orientação que se pretendia seguir na montagem de um mercado americano abastecido por produtos espanhois e transportados em navios tambem espanhois. Dir-se-ia tratar-se, agora, de uma Espanha governada por espanhois para os problemas espanhois.

(12). - Impresso em Madrí, "de orden de su Magestad, En la Imprenta de Juan de Ariztia", em 5 de abril de 1720. Acha-se publicado in Levene (Ricardo), Documentos para le Historia Argentina, tomo V (1713-1778), págs. 21 e segs. Buenos Aires, 1915.

(13). - Cf. "Proycto para Galeones y flotas", pág. 26. 
A Ordenança de 1720 não representa ainda a "liberdade" de comerciar. Mas indica, porem, a transição para um sistema colonial mais concordante com a realidade conjuntural do Império, passo largo na direção do estabelecimento do "Comércio Livre", visto defender-se a necessidade de uma profunda reformulação do regime de exploração do tráfico ultramarino. A abertura do mercado americano para produtos espanhois e a exigência de serem os navios de construção nacional consubstanciam os movimentos que já vinham se adensando no sentido de uma profunda reformulação do sistema colonial. As medidas fixadas representaram, sem dúvida, uma revisão nos métodos rígidos até então presentes com relação ao tráfico americano. $\mathrm{E}$ as imperfeições que incidiam na política econômica foram em boa parte sanadas pelas correções gradativas que a Coroa realizou.

No mesmo ano de 1720 , em 23 de maio, logo depois do "Proyecto para Galeones y flotas", a realeza dirigiu aos Intendentes das diversas Províncias do reino uma Ordem Circular a fim de encorajarem os empresários industriais de seus distritos a embarcarem seus artigos nos navios que operavam nas rotas americanas (14).

Medidas para promover o fomiento do reino, regular e controlar a partida e a torna-viagem das frotas de Nueva España e do Perú foram tomadas em razão do interesse que não era mais, unicamente, o do monopólio gaditano. O aperfeiçoamento representava um abalo, embora não profundo, na estrutura do mercantilismo tradicional da dinastia anterior. Foi, sem dúvida, uma inovação a exigência régia de 5 de abril de 1720 nacionalizando as duas frotas - gêneros e navios apenas espanhois - não obstante as discrepâncias que, certamente, subsistiram entre a lei e a realidade.

A experiência resultante dos "navios de registro y avisos" asseguraria determinados estímulos ao setor industrial e mercantil. Com isso a burguesia da linha periférica, notadamente dos portos de Barcelona e San Sebastian, admitiria sua participação direta no tráfico americano, o que equivaleria à ruptura do monopólio do Consulado de Cadiz.

A necessidade de se estender o benefício aos portos do Mediterrâneo e do Cantábrico, a fim de melhor assegurar-se o crescimento harmônico da economia do reino, era uma estratégia da Coroa que encontraria descontentamentos nas agremiações do alto comércio de Cadiz, bem como de seus apaniguados do ultramar - os Consulados de Lima e México. As medidas da realeza atendiam às aspirações das

(14). - Cf. Acevedo (R. Antuñez y), Memorias historicas sobre la legislación y gobierno del comercio de los españoles con sus colonias en las Indias Occidentales, pág. 108. Madrid, 1797. 
forças sócio-econômicas do Mediterrâneo e do Cantábrico. Mas, em contrapartida, não agradavam à liderança gaditana. Filipe $\mathrm{V}$, assessorado por Patiño, detentor do governo econômico da "carrera" das Indias, poder que procedia de seu alto cargo de "Intendente da Marina y Presidente de la Casa de la Contratación", compreendeu que o tráfico vinha sendo prejudicado por muitos portos de estrangulamento, malefício que se originava no próprio sistema de exploração colonial.

Impunha-se, portanto, uma nova estratégia do desenvolvimento, confiando-se à empresa privada a responsabilidade de impulsionar o processo de crescimento. Sem transferir, porem, o exclusivismo de Cadiz e dos Consulados de Lima e México para a Espanha e América periféricas, o trono confirmou seu propósito de assegurar o pleno progresso da "livre-empresa" coexistindo, embora não de forma harmônica, com o monopólio gaditano vigente. O mercantilismo tradicional sofreu, com a inovação, um novo golpe. Dir-se-ia vigorar, agora, um mercantilismo mais apropriado à conjuntura regional e mais identificado com os anseios da burguesia dos portos marítimos do reino e do ultramar.

Instituiu-se, então, ainda no reinado de Filipe $\mathrm{V}$, uma nova etapa experimental de exploração do tráfico americano - o sistema das Companhias de Comércio. A política da monarquia centralizada caracterizava-se ainda por uma conjuntura marcada pelo monopólio, que só pode justificar-se pelo receio do trono. Todavia, obteve-se, com a mudança do regime, um dimensionamento do trânsito colonial. Por outro lado, a reforma do sistema possibilitou maior intercâmbio de informações consubstanciadas no alargamento das idéias da "Ilustração" estrangeira, sobretudo francesa, em Espanha e na América.

Com as Companhias, a Coroa instituiu outra modalidade de monopólio sem acabar com o exclusivismo de Cadiz. Não chegou a substituir um monopólio por outro. Ambos coexistiram, cada qual a seu modo e de conformidade com o ordenamento que lhes foi dado pelos favores da realeza.

Com isso os primeiros Borbons - Filipe V (1701-1746) e Fernando VI (1746-1759) - ofereceram certas oportunidades à Espanha periférica (Catalunha e País Basco) que tornaram possivel a abertura de brechas no concretado monopólio tradicional. O sistema nada tinha de original, visto ser de inspiração estrangeira. Ademais, já os últimos Habsburgos - Filipe IV (1621-1664) e Carlos II (16651700) - haviam compreendido o papel desempenhado pelas Companhias. Os primeiros delineamentos para a criação de tais empresas de 
direito privado em Espanha datam de 1624, ano em que foram apresentados à Coroa dois projetos para o estabelecimento de Companhias: para as Indias Ocidentais de Espanha, um; outro para o tráfico com o Oriente. Semelhantes iniciativas malograram, todavia, consoante informe duma memória assinada por Francisco de Salas, datada de 28 de setembro de 1676, que se acha na Secção de Manuscritos da Biblioteca Nacional de Madrí (15).

Nesse sentido, ainda no reinado de Filipe IV, novos planos foram elaborados. Em 1628 o soberano nomeou uma comissão encarregada de estudar a montagem de cinco Companhias destinadas ao comércio com as praças do "Levante, Norte, Terra Nova, Indias Orientales y Occidentales" (16). E no governo subsequente, na administração de Carlos II, "Don Luis Cerdeño y Monzón, membro del Consejo de Indias y da Junta concerniente a la Formación de Compañias", em outubro de 1683, já no ocaso da dinastia dos Áustrias, delineou uma Companhia para o comércio entre Espanha e a América (17).

A Coroa procuraria, com tais expedientes, contrapor-se à investida do mercantilismo salteador internacional utilizando-se das mesmas armas - Companhias contra Companhias. Os projetos fracassaram. Certamente esbarrariam nos interesses do monopólio gaditano.

Com os Borbons é que se criaram condições propícias ao estabelecimento de Companhias em Espanha. O século XVIII espanhol foi o século das Companhias. A América - em todas suas terras e águas - despertava apetites alienígenas e nacionais. A linha periférica do reino de há muito desejava internar-se na urdidura do tráfico colonial. Só agora é que a Coroa lhe daria o fundamento legal para o empreendimento.

Logo nas primeiras décadas da centúria, em 1728, instituiu-se a "Real Compañia Guipuzcoana de Caracas", com o privilégio do comércio na Província de Venezuela e em Cumaná, Trinidad, Guayana e Margarita (18).

(15). - "Relación sucinta de lo que ha passado sobre la institución de la Compañia de Comercio en Vidal del Rey Nuestro Señor (que Santa Gloría aya), y el estado que hoy tiene" - por Francisco de Salas. Madríd, 28 de setembro de 1676, in B.N.M. - Ms. $n^{\circ} 11.029$. 1952.

(16). - Cf. Diccionario de Historia de España, t. I, pág. 708. Madrid,

(17). - "Botto de Don Francisco de Fé en la Junta de Comezzio sobre lo propuesto en ella tocante a la formazion y Establezimiento de Una Compañia Española Armada para el trafico y Comerzio de España con las Indias Occidentales y sus Islas y Puerttos". Madrid, 8 de setembro de 1683 (B.N.M. - Ms. no 11.029).

(18). - Apesar dos estudos de Ronald D. Hussey (La Compañia de Caracas, 1728-1784 - publicado em 1948 na "Revista de Hacienda", Ano 
Ainda no reinado de Filipe V, por Real Cédula de 29 de março de 1733, projetou-se outra Companhia para o comércio com as Filipinas. Semelhante empresa só foi instituída nos últimos anos do século, graças à Real Cédula dada por Carlos III em 10 de março de 1785 (19).

Destinada ao fomento da agricultura comercial do açuçar e do tabaco já havia sido criada em 1740 a "Compañia de la Habana". E em 1752 a "Real Compañia de Barcelona", com privilégio de comércio com a Venezuela (20). Três anos depois, em 1755, instituiu-se' a "Compañia de Santo Domingo e de Cataluña" para o tráfico com Santo Domingo, Puerto Rico e Margarita (21).

Outras entidades foram criadas no decurso do século XVIII para o fomento do reino, embora com vida curta e acidentada. A principal foi a "Compañia de los Cinco Gremios Mayores de Madrid". Em 1746 surgiram mais duas sociedades: a "Compañia de Aragón" e a de "Zarza la Mayor". E no ano seguinte foi estabelecida a "Compañia de San Fernando de Sevilla", com alguns privilégios para operar no Caribe, sem entretanto poder interferir na jurisdição e competência reservadas às Companhias de Caracas e de Havana. E entre $1748 \mathrm{e}$

XIII, n9s 25,26 e 27, em Caracas, e mais tarde reeditada pelo Banco Central da Venezuela, em 1962) e de Nicolas de Soraluce y Zubizar ieta (Historia de la Real Compañia Guipuzcoana de Caracas. Madrid, 1876), a Companhia de Caracas reclama ainda certas bordgens dilucidtivas. Um rico acervo acha-se no "Archivo General de la Nación", em Caracas, no "Archivo General de Indias", em Sevilha e no "Archivo Provincial de Guipuzcoa". Os Estatutos da empresa, assinados por Don José Patiño, datam de Madiid a 25 de setembro de 1728, e se encontram impressos nos referidos Arquivos de Caracas e Sevilha (Cf. Real Cédula de fundación de la Real Compañia Guipuzcoana de Caracas y reglas economicas de buen gobierno. Madrid, 1728).

(19). - Cf. "Aclaración necesaria para la buena inteligencia de las tres indicaciones del señor Diputado Don Agustin Rodriguez Baamondi sobre la Compañia de Filipinas". Madrid, 1820; "Exposicion de la Compañia de Filipinas Relativa a su Establecimiento, y a su impo-tancia politico-mércantil". Cadiz, 1813; "Real Cédula de Erección de la Compañia de Filipinas". Madrid, 1785. Veja-se ainda o estudo de M. L. Diaz - Trechuelo Spinola, La Real Compañia del Filipinas. Sevilha, 1965.

(20). - Cf. Vila (Marco Aurelio), La Real Compañia de Comercio de Barcelona en Venezuela, 1752-1816. Separata da "Revista de História" $n^{\circ} 2$. Caracas, 1960.

(21). - As Companhias borbônicas aguardam apuração das quantidades de seu giro. No "Archivo Historico Nacional", em Madri, acha-se valioso núcleo documental atinente a Companhia de Havana (Cf. "Papelos de Estado pe:tencientes a Indias. Compañia de Comercio de la Habana" 2.320). Veja-se ainda, neste Arquivo, o "Diccionario de Gobierno y Legislación de Indias" de Manuel José de Ayala. Acha-se impresso o Estatuto da "Real Compañia de Comercio para las Islas de Santo Domíngo, Puerto Rico y la Margarita, que se ha dignado el Rey conceder". Madrid, 1756. 
1773 criaram-se as de Toledo e Burgos para a recuperação econômica do reino (22).

O impulso data das administrações dos dois primeiros Borbons - Filipe V (1701-1746) e Fernando VI (1746-1759) - respectivamente assessorados por Patiño e Campillo. Mas no reinado seguinte - no de Carlos III (1759-1788) - com a proficiência de Floridablanca, Aranda, Campomanes, Roda, Jovellanos, Olavide, Saavedra e Gálvez, é que teve início a fase autêntica de renovação das estruturas do sistema colonial espanhol. A população do reino aumentara. No ocaso do século XVII era estimada em menos de seis milhões de habitantes. No meado da centúria subsequente elevou-se a mais de sete, ultrapassando dez milhões de almas em 1778, conforme apuração feita pelos oficiais da "Junta de Cadastro" mandada organizar por Carlos III (22). As Províncias de maior densidade demográfica eram, então, Guipúzcoa com oitenta habitantes, Valência com quarenta e oito, Navarra com quarenta e três, Vizcaya com quarenta e dois e Astúrias com quarenta e um habitantes por quilômetro quadrado (24).

A colonização interna figurava no programa das reformas estruturais. Já Jovellanos, em sua dissertação da "ley agraria", lamentava a desproporção entre a densidade demográfica dos centros urbanos e a escassez de gente válida na zona rural, onde os pequenos "pueblos" estavam quase desertos (25).

$O$ fomento do reino vinha projetado desde os reinados anteriores ao de Carlos III. Já na administração de Fernando VI, nos anos de 1749 e 1750, foram encaminhados ao ministro Enseñada projetos de Don José Borrás e do Marquês del Puerto recomendando o repovoamento de certas regiões do País com a imigração de católicos oriundos da Europa Central, especialmente alemães e húngaros. Mais tarde, em 1776, Carlos III recebeu do coronel bávaro Thurriegel um ofere-

(22) . - Cf. "Real Cédula de la Compañia de Fabricas y Comercio de Sevilha, Madrid, 1747; Archivo de Simancas. Hacienda, legajos n's. 885-857. Veja-se ainda o artigo de Carmelo Viñas Mey - Las Compañias de Comercio y el resu-gimiento industrial de España en el Siglo XVIII, in Revista Nacional de Economia, págs. 239 e segs. Barcelona, 1922.

(23). - Cf. Casado (Vivente Rodriguez), Poltica interior de Carlos III. t. I, pág. 18. Simancas, 1950; Bleyle (P. Aguado) - Molina (C. Alcazar), Manual de Historia de España, t. III, págs. 376 e segs. Madrid, 1956.

(24). - Ibidem.

(25). - Afigurava-se-lhe produtiva uma Espanha "mas uniforme y razonablemente problada, y no sepultada en los cemeterios de las capitales" (Cf. "Informe de una ley agraria". pág. 5, Madrid, 1795).

(26). - Pablo José de Olavide y Jáureguí nasceu em Lima no ano de 1725. Protegido por Aranda tornou-se um dos assessores de Carlos III. Em 1775 foi denunciado à Inquisição. Em 1778 foi condenado a oito anos de reclusão. Em 1780 fugiu para a França, onde conviveu com Diderot e outros "iluminados". Em 1798 retornou a Espanha anistiado por Carlos IV. 
cimento de seis mil emigrantes, muitos dos quais se mostravam desejosos de colaborar na colonização de Puerto Rico ou doutras regiões americanas. O monarca solicitou parecer a D. Pablo José de Olavide y Jáuregui (26), logo encaminhado ao "Consejo" que o aprovou em 1767. Graças à justificativa apresentada e defendida por Don Pedro Rodríguez Campomanes, diversas famílias alemãs e flamengas foram encaminhadas para a recolonização de Sierra Morena, bem como, por conselho de Olavide, juntamente com colonos doutras procedências, para Ciudad Rodrigo e Andalucía (27).

O repovoamento do hinterland do País, em que o poder público associou-se à poupança privada, nacional e estrangeira, constitui uma das obras de maior vulto do reformismo de Carlos III em sua primeira fase. Mais tarde, a empresa de colonização do interior do reino estruturou-se no ordenamento delineado pelo veneziano Jacques Casanova de Seingal que, em suas "Memórias", influenciou a Coroa e seus assessores "esclarecidos" a programar ajuda oficial no sentido de incentivar a ruralização da economia com colonos apenas nacionais, e em regiões irradiadoras do povoamento distanciadas do alcance do Santo Ofício - empecilho ao fomento agrícola (28).

A renovação das estruturas fazia-se na trama legislativa dos Ministérios, cada vez mais importantes e absorventes das antigas atribuições dos "Consejos". Em 1787 instituiu-se o "Consejo de Ministros", por proposta de Floridablanca, ente moral de direito público suprimido mais tarde, em 1792, pelo Conde de Aranda, já na administração de Carlos IV. Os "Consejos de Estado, de Castilla, de Indias, Ordenes, Guerra, Hacienda y Camara de Castilha" tornaram-se famosos como corpos consultivos e deliberantes. O "Real Consejo de Castilla" era o mais poderoso. Em 1766, no tempo de Carlos III, compunha-se de trinta conselheiros e três fiscais assistidos por uma montagem burocrática integrada por escrivães, oficiais maiores, relatores e porteiros. O seu presidente era a mais alta figura do Estado, depois do rei, e exercia poder de legislar em nome da Coroa. Redigia as ordenanças, pragmáticas, decretos, regulamentos, ordens, editos e bandos. Armipotente ente autárquico de controle, o "Consejo de Castilla" detinha faculdades de Supremo Tribunal de Justiça, de Ministério da Econo-

(27). - Cf. Campomanes (P. R. Conde de), Tratado de la regalia de amortización pág. 11. Madrid, 1765; Pereira (L.M.), Reflexiones sobre la Ley agraria que se esta tratando en el Consejo, pág. 13 e segs. Madrid, 1788; Quintero (MM. I. Perez), Pensamientos políticos y economicos dirigidos a promover la agricultura y demás ramos de industria, a extinguir la ociosidad y dar ocupación honesta y util a todos los brazos, págs. 4 e segs. Madrid, 1798.

(28). - Dézert (G.M. Desdevises du), L'Espagne de l'Ancien Régime, t. I, págs. 67 e segs. Paris, 1899. 
mia e da Instrução Pública (29). Embora nele figurassem prelados e elementos da nobreza agrária e militarista, predominavam em seu corpo representantes da burguesia intelectual - letrados, ilustres jurisconsultos e professores catedráticos (30).

No processo de renovação da economia interna do reino figura uma instituição de direito público, de origem francesa e engenho do despotismo "ilustrado" - o Intendente de Província, criado por Filipe V com o objeto de ordenar a administração regional nos setores da agricultura, da indústria e do comércio. Mais tarde, em 1749, Fernando VI revigorou-se, conferindo aos Intendentes os assuntos de Justiça, Hacienda, Guerra y Policia". Com Carlos III, porem, é que se definiu e se consagrou pelos resultados alcançados no reino e no Ultramar. A Coroa recebia a assistência ministerial adequada de Pedro Rodrigues Campomanes e Gaspar Belchior de Jovellanes, bem como a ajuda das "Sociedades Econômicas de Amigos del País", com seu programa altruista e humanitário (31).

Dados os resultados obtidos, multiplicaram-se pelo País as "Sociedades Econômicas". A primeira a ser criada foi a "Vascongada", estabelecida em 1763 em Villafranca, na "Junta de la villa de Azcoitia", aprovando-se três anos depois, em 1776, o seu Estatuto. Seguiram-se outras congêneres, mas apenas em 1775 , com a criação da "Sociedade Econômica de Madrid", proposta por Campomanes e integrada por "personas de calidad" - letrados e elementos do alto comércio - é que se definiu essa modalidade de fomento do reino (32).

Os "Amigos del País" associaram-se aos assessores do trono políticos e economistas "iluminados" pelas "luzes" do século. O mais equilibrado foi Campomanes. Embora adepto da fisiocracia francesa, defendia com proudência as conveniências de se aplicarem as idéias alienígenas de conformidade com a realidade nacional espanhola. Era

(29). - Cf. Arrieta (P. Escolano de),Práctica del Consejo Real en el despacho de los negocies consultivos, instructives y contenciosos, vol. I, págs. 13 e segs. Madrid, 1796; Déert (G.M.), Le Conseil de Castille au XVIII siècle, in "Revue Historique, págs. 67 e segs. Paris, 1902; Alcazar (Cayetano), El Conde de Floridablanca, págs. 33 e segs. Múrcia, 1934.

(30). Ibidem.

(31). - Cf. Coxe (William), Memoirs of the Kings of Spain of the House of Bourbon, págs. 93 e segs. Londres, 1815; Rio (A. Ferrer Del), Obras originales del Conde de Floridablanca, y escritos referentes a su persona, in "Biblioteca de autores españoles", t. LIX. Madrid, 1912; Villa (A. Rodriguez), Cartas politico-economicas escritas por el Conde de Campomanos al Conde de Lorena. Madrid, 1878; Requejo (F. Alvarez), El Conde de Campomanes, su obra histórica. Oviedo, 1954.

(32). - "Una de las mas típicas manifestaciones de la nueva corriente de ideas que circulo por España en la segunda mitad del siglo XVIII" (Cf. Diccionario de Historia de España, t. II, pág. 1.193. Madrid, 1952. 
partidário do revigoramento do trabalho manufatureiro mediante a instrução popular. Preocupava-o o problema da mão-de-obra qualificada. Em seus "Discursos" sobre o industrialismo do reino e educação "de los artesanos" - em cujos apêndices figuram estudos de economia e traduções de manuais técnicos - indicou à Coroa programas para o fomento de economia nos seus setores da agricultura, do comércio e da manufatura (33).

$O$ incitamento processava-se sob influência francesa. A renovação era de nítida fisionomia fisiocrática. A literatura dos teóricos economistas e o programa das "Sociedades de Amigos del País" inspiravam-se no pensamento da Escola de Quesnay. Já em 1703 havia sido comissionado por Filipe V Naranjo Romero, admirador de Colbert e dos políticos franceses, para estudar a montagem de fábricas em Espanha. Nas províncias de Cuencas, Guadalajara, Soria, Burgos, $\mathrm{Pa}-$ lencia, Toledo, Córdoba e Jaén haviam manufaturas ligadas aos tecidos de seda e fios de ouro, bem como de "holandas" e "mantelerías" em Galícia, embora de qualidade inferior às de França, Holanda e Inglaterra, a ponto da Corte adquirir no estrangeiro o vestuário e as guarnições de que precisava (34).

Para impedir a fuga de metal nobre para fora do reino, Filipe $\mathrm{V}$ criou as "Reales fábricas de panos" em Guadalajara, San Fernando, Chinchón, Segovia e Brihuega. Montou ainda indústrias de cristais em La Granja, bem como de seda em Talavera e de tapeçarias em Madri, tomando-se por modelo a manufatura de Flandres (35).

Nessa linha inovadora Carlos III estabeleceu a indústria dos algodões de Ávila e das porcelanas "del Retiro", instigado pelos seus assessores partidários das idéias de Adam Smith atinentes à liberdade produtiva. Em Rentería (Guipuzcoa) incrementou-se a fundição de ferro com técnicos alemães. Ressalta ainda a contribuição de mãode-obra qualificada sueca, alemã e inglesa na exploração mineira de Guadalcanal, bem como a melhora da fiação e tecelagem de algodão na Catalunha, indústria que vinha superando a da lã e a da seda. Me-

(33). - Campomanes (Cf. "tratado de la regalía de amortización". Madrid, 1765, defendia o trabalho manufatureiro mediante a instrução popular. Madrid, 1765; "Discurso sobre el fomento de la Industria popular". Madrid, 1774: "Discurso sobre la educación popular de los artesanos y su fomento", Madrid, 1775). defendida o incremento das manufaturas do reino mediante a formação de mão-de-obra qualificada.

(34). - Cf. Dezert (G.D.), L'Espagne de l'ancien regime, págs. 63 e segs.,cit., ed.; Orsi (M.P.), 'L' Espagne et le Portugal. Souverains et ministres reformateurs (1724-1788Q, in "Hist. Gen." de Lavisse-Rambaud, t. VII, págs. 982 e segs. Paris, 1896.

(35). - Ibidem. 
recem ainda registro as "herrerías" na região basca, a mineração nas Astúrias, o papel em Alicante e o vidro branco em Barcelona (36).

O século XVIII foi fertil em engenhos técnicos. As indústrias extrativas e transformadoras formavam o embasamento do capitalismo europeu, notadamente o britânico, e eram para ele, sobretudo, o principal centro de atração dos investimentos oriundos dos disponíveis realizados pelas grandes expropriações das economias tradicionais. $\mathbf{O}$ progresso do industrialismo, caracterizando-se pela importância dos empreendimentos e condicionando um maior rendimento de trabalho, aceleravam o rítmo da produção. E o comércio internacional - a um só tempo causa e efeito duma produção em massa - facultava a exploração intensiva das matérias primas e impunha o alargamento dos mercados e escápulas, no continente e no ultramar.

O rico patrimônio dos Borbons de Madrí continuava, mais do que nunca, no âmbito dos interesses do capitalismo europeu, então revigorado com a transformação do capital comercial em capital industrial. Porisso o esforço da monarquia espanhola devia necessariamente estender-se à salvaguarda do manancial americano ameaçado pela avidez das grandes potências concorrentes.

O problema vital para a Espanha consistia em manter a segurança das ligações com os diversos "eixos" americanos. O revigoramento da economia interna do reino não bastava. Impunha-se a defesa das rotas de tráfico indiano e o amparo do patrimônio colonial, de cuja seiva dependia em grande parte o prestígio da metrópole. Eliminar o comércio ilícito de nacionais e estrangeiros era problema que precisava ser resolvido pela monarquia centralizada. $O$ fomento do reino e a segurança do império figuravam no mesmo processo renovador das estruturas. As "charneiras" atlânticas - o Caribe e o Prata - viviam desassossegadas e, por dependência, todo o giro intercolonial e o trânsito oceânico em ambas costas americanas.

Esse amontoado de questões a resolver conjugava-se com os anseios da Espanha periférica, há muito inconformada com o monopólio gaditano. Os armadores do Cantábrico e do Mediterrâneo já haviam adentrado no tráfico direto com as praças americanas através das Companhias de Caracas e Barcelona, expediente que revelou o poderio dos empresários da Catalunha e do País Basco. Contudo, semelhantes concessões régias despertaram ainda mais a burguesia dos

(36). - Dezert (G.D.), Idem, págs. 72 e segs; Casado (V. Rodriguez), De la monarquia española del Barroco, págs. 52 e segs. Madrid, 1954; La revolución burguesa del XVIII español, in "Arbor", 18, págs. 42 e segs. 1951; La política y los politicos en el reinado de Carlos III, págs. 92 e segs. Madrid, 1962; Atard V. Palacio A, El despotismo ilustrado español, in "Irbor", 8, págs. 11 e segs. 1947. 
portos marítimos. Comerciantes e marinheiros de Santander, Barcelona, La Coruña, Málaga, Gijon, Alicante e El Ferrol, irmanados a outros empórios da metrópole e do ultramar, romperam as cadeias do conformismo tradicional e investiram, através dos políticos e economistas assessores de Carlos III, contra o monopólio gaditano.

Congraçar um exclusivismo com outro - o de Cadiz com o das Companhias de Caracas e de Barcelona, ou de outras congêneres não solucionava os entraves. Liberalizar o tráfico americano, abrindo a linha dos portos marítimos do reino e da colônia ao giro mercantil parecia ser ato de política econômica mais consonante com as ansiedades nacionais e com a filosofia da "Ilustração".

Em vista de tais anseios e comprimido pela conjuntura, a Coroa foi levada a experimentar um novo regime de exploração do comércio indiano - terceiro ensaio - meio de satisfazer o alto comércio da Espanha periférica e de seus políticos "iluminados". E no âmago desse pluralismo de fatores convergentes engendrou-se a nova etapa do sistema colonial espanhol, que se configurava salvadora: a instituição do "Comércio Livre" entre o reino e sua Indias Ocidentais.

O reformismo visava a descentralização do tráfico americano e o melhor entrosamento dos interesses do trono com as conveniências da burguesia do Cantábrico e do Mediterrâneo. Reconheceu a Coroa que o maior mal era o monopólio. Porisso acabou com ele sem, contudo, liberar inteiramente o tráfico. Optou pelo meio termo - transição entre o mercantilismo tradicional decadente e o liberalismo alienígena recem-nascido. Com isso Carlos III escamoteou o problema sem resolver totalmente a questão. Não rompeu integralmente com os valores "tradicionais". Tampouco aceitou, sem reticências, o liberalismo das "luzes" estrangeiras. Preferiu o que lhe pareceu mais harmônico com a realidade nacional. E do mesclado do "novo" com o "velho" surgiu uma singular variante do sistema colonial espanhol: o mercantilismo "ilustrado" (37).

O tráfico tornou-se então "livre" na medida em que se tornou, porquanto a realeza reservou para si e para o alto comércio de Cadiz certas prerrogativas de natureza econômica. Ademais, o novo sistema não exterminou logo com o regime das Companhias. Estas empresas coloniais tiveram seus privilégios respeitados e sua ação continuou a fazer-se nas respectivas áreas circunscritas ao seu monopólio, de conformidade com seus Estatutos delegados pelo favor réglo.

(37). - Veja-se nossa tese: O "Comércio Livre" entre Havana e os portos de Espanha (1778-1789), vol. I, pág. 124. São Paulo, 1965. 
A instituição do "Comércio Livre" exprimia, afinal, as próprias contradições de um sistema colonial decadente. O novo ensaio era de feição alienígena e se fundia com os ideais dos enciclopedistas teóricos e com a utilidade prática dos revolucionários franceses irmanados com os assessores de Carlos III. A experiência constitui um marco no processo da variação do ordenamento colonial espanhol que solapou toda ordem econômica até então vigente.

As profundas transformações estruturais realizadas na Espanha borbônica formaram o ambiente propício a uma infiltração da Fisiocracia geradora do liberalismo, seu filho dileto. Floridablanca, Aranda, Olavide, Jovellanos, Campomanes, Roda e Saavedra, todos eles, com suas cambiantes, foram influenciados pelas diferentes formas de especulação filosófica e científica do século "iluminado". As "Sociedades Econômicas de Amigos del Pais", que se estenderam por toda Espanha e passaram à América no decurso da segunda metade da centúria, foram organizadas nos moldes da Ilustração francesa (38). Os "doutores" de Carlos III foram buscar na experiência estrangeira a inspiração para suas reformas. Políticos e economistas "populares" a cavaleiro do trono procuravam, com as "luzes" importadas, descortinar uma dimensão inteiramente nova que a Espanha não compreenderia totalmente.

A maneira das Companhias e das Intendências, as Sociedades Econômicas foram entidades importadas - encontros de jovens fidalgos educados em França. Criava-se então um clima propício à renovação nas tertúlias, nos cafés, na Corte e nas "Econômicas". As reuniões eram em estilo francês e "ilustradas" (39). Os Borbons eram de cepa francesa. Todo processo do reformismo espanhol era de influxo alienígena sem, contudo, apresentar uma linha de pensamento, inconveniente que desfigurou certos institutos de direito público e de direito privado criados pela monarquia para a renovação do reino e fomento colonial. E que nenhum dos planejadores teóricos que assessoravam a realeza tinha originalidade. Daí a "assimilação" do que importavam.

O movimento renovador datava do tempo de Filipe V (17011746) com Jerônimo de Ustáriz e José del Campillo (40). Acentuara-

(38). - Cf. Novoa (Emílio), Las Sociedades Económicas de Amigos del País, págs. 67 e segs. Madrid, 1955; Urquijo (Julio de), Los Amigos del País, págs. 51 e segs. San Sebastian, 1929; Menedez Pelayo e los Caballeritos de Azcoitia, págs. 43 e segs. San Sebastian, 1925.

(39). - Hazard (Paul), El pensamiento europeu en el siglo XVIII, págs. 61 e segs. Madrid, 1960; Novoa (Emílio), op. cit., págs. 82 e segs;; Urquijo (Julio), op. cit., págs. 73 e segs.

(40). - Vejam-se os escritos de Ustáriz (Teoria y Práctica del Comercio y de la Marina. Madrid, 1757) e de Campillo (Nuevo sístema de gobierno -conomico para la America. Madrid, 1743). 
-se no decurso da administração de Fernando VI (1746-175) com a política de Ensenada e do Conde de Peñaflórida (41). Precipitou-se, porém, no governo de Carlos III (1749-1788) com seus auxiliares "iluminados" pelas "luces del siglo". Todos eram adeptos fervorosos do "enciclopedismo" e partidários fiéis de "libre pensamiento" (42).

O período mais "ilustrado" foi o de 1766 a 1788, que corresponde aos últimos vinte e dois anos do reinado de Carlos III. Nesse decurso de tempo lutaram com sutileza "reformistas" e "reacionários". O Conde de Aranda e seus partidários formavam os chamados "aragoneses". Até 1773 Aranda foi presidente do "Consejo de Castilla". Era um "grande" de Espanha e contava com o apôio dos "arandistas", fielmente representados pelos fiscais do "Consejo de Castilla" - Moñino e Campomanes - que desfrutavam de enorme prestígio na Corte. Não obstante suas hesitações, Aranda foi o melhor instrumento político da burguesia dos portos marítimos. Antes de tudo era um reformista. Na Embaixada de Espanha em Paris montou o ajuste com os planejadores das reformas. A partir de 1773 suas "luces" diminuiram de brilho, com a elevação de Don Manuel Ventura de Figueroa, nesse mesmo ano, à presidência do "Consejo de Castilla". Mas logo depois foi substituido nesse alto cargo por Campomanes, o veterano fiscal "del Consejo", onde se manteve até 1791, já no reinado de Carlos IV, depois de servir nos restantes anos do governo de Carlos III (43).

Em 1777, Floridablanca tomou posse na Secretaria de Estado. Desse ano até 1788, fim do reinado de Carlos III, Campomanes e Floridablanca formaram o "eixo" político inovador. Ambos foram mantidos nos seus cargos por Carlos IV. Outros políticos integraram com Campomanes e Floridablanca a "elite" dos estadistas espanhóis do séjulo XVIII. Merece referência Don Miguel de Múzquiz, ministro de "Hacienda" e Conde de Gauna, que morreu em 1785. Substituiu-o, por indicação de Floridablanca, Don Pedro López de Lerena. Ressal-

(41). - Cf. Hazard (Paul), op. cit., págs. 77 e segs.

(42). - Ibidem; Sarrailh (J.), L'Espagne éclairée de la seconde moitié du XVIII siècle, págs. 103 e segs. Paris, 1954; Danvila (M.), Reinado de Carlos III, vol. I, págs. 97 e segs. Madrid, 1891; Muriel (A.), Gobierno de Carlos III; págs. 68 e segs. Madrid, 1839.

(43). - Cf. Casado (V. Rodríguez), La politica y los politicos en el reinado de Carlos $11 I$, págs. 217 e segs. Madrid, 1962; Requejo (Alvarez), El Conde de Campomanes. Su obra histórica. págs. 23 e segs. Oviedo, 1954; Perez (Muñoz), La idea de Ameríca en Campomanes. in "Inuario de Estudios Americanos", págs. 209 e segs. t. X. Sevílla, 1953. De Campomanes, vejam-se os escritos seguintes: Tratado de la Regalia de Amortización Madrid, 1765; Juício Imparcial. Madrid, 1769; Discurso sobre el fomento de la industria popular. Madrid, 1774; Discurso sobre la educacion popular de los artesanos y su fomento. Madrid, 1775. 
ta ainda a figura de Don José de Gálvez. A morte de Don Julian de Arriaga, ministro da "Marina y Indias", em 1775, foi a oportunidade para Gálvez ser empossado na Secretaria de Indias, separada nesse ano da de "Marina", para cujo despacho foi então nomeado Don Pedro González de Castejón (44).

A atuação de Gálvez à frente da Secretaria das Indias acha-se inserida no ordenamento de quatro importantes instituições hispano-americanas, todas elas demonstrativas do esforço renovador da administração dos últimos Borbons de Madrí: a extensão do sistema de Intendências, o estabelecimento do "Comércio Livre" e as criações do "Virreinato del Plata y de la comandancia General de Provincias Externas". Gálvez, pela sua atuação no âmbito das reformas estruturais, figura no rol dos grandes do tempo, ao lado de Campomanes, Aranda e Floridablanca, contribuindo sobremaneira para a mudança do sistema colonial espanhol e penetração das "luces" na América (45).

A tendência da Espanha "ilustrada", no reino e no ultramar, manifestava-se, então, notadamente no setor da vida econômica. As novas instituições, umas de direito público, outras de direito privado, organizaram-se, porem, nos moldes da monarquia centralizada e em consonância com a filosofia política do despotismo esclarecido. À Coroa não convinha "reformar" para debilitar sua autoridade incontrastavel. E o que testemunham os Estatutos da "Secretaria del Despacho" e "Ministério de Indias", ordenados em 1717, no começo do reinado de Filipe V; dos novos "virreinatos de Nueva Granada" e de "Rio de la Plata", respectivamente instituidos em 1730, ainda no governo de Filipe V, e em 1776, já no reinado de Carlos III; da "Capitanía General de Venezuela", em 1777; das Audiências de Buenos Aires, Caracas e Cuzco, respectivamente em 1783, 1786 e 1787; da "Comandancia General de las Provincias Internas", em 1776, para atender ao fomento; dos Intendentes que, a partir de 1776, se estenderam por toda a América Espanhola; da supressão das frotas e feiras, entre 1738 e 1740; dos navios "correos mensueles", em 1764; da abolição do regime de "puerto único", em 1764; da permissão do sistema de comércio intercolonial, em 1774; da extinção da obsoleta "Casa de la Contratación", em 1799 - anos depois de sua passagem de Sevilha para Cadiz; da montagem do Real Consulado de Caracas, em 1793, o primeiro Consulado moderno instituido na América, ao qual se seguiram os seus congêneres de Guatemala, Buenos Aires, Havana e Santiago do Chile, no decurso de 1794 e 1795; das "Sociedades Econô-

(44). - Casado (V. Rodriguez), op. cit., págs. 246 e segs.

(45). - Cf. Priestley (H. Ingram), José de Gálvez, visitador general of New Spain, 1765-1771, págs. $68 \mathrm{e}$ segs. Berkeley, 1916; The reforms of José Gálvez in New Spain, págs. 93 e segs. New York, 1917. 
micas de Amigos del País", iniciadas no ultramar com o estabelecimento da de Quito, em 1791, e a de Havana em 1793 (46).

Semelhante renovação institucional ficaria para a História como admiravel herança dos assessores do trono. Com ela surgiram novas possibilidades de crescimento orgânico, intensificando-se o giro intercolonial e o trânsito entre Espanha e suas Indias Ocidentais. Alargaram-se novos horizontes políticos e novas aspirações capitalísticas, esboçando-se e estruturando-se no circuito das reivindicaçōes nacionalistas crioulas o germe de cooperação emancipacionista dos "próceres" da Independência da América Espanhola, seguidores das doutrinas do século "iluminado" (47).

Contudo, a Espanha não exprimiu, de modo algum, pelas suas condições econômicas, sociais e políticas, as tendências ou as exigências da Europa revolucionária. Pela sua própria imaturidade capitalista e pela sua obsessão centralista, a monarquia achava-se, dir-se-ia, ausente daqueles propósitos de revolvimento estrutural. Pela sua evolução particular e pelas suas próprias composturas a Espanha realizaria, porem, a seu modo, os seus desígnios. O reino vivia mais voltado para dentro e ainda preso ao passado. Porisso a Coroa hesitava afastando-se, sob muitos aspectos, das lides do liberalismo político e econômico da Europa capitalista. O próprio Carlos III titubearia integrar-se no movimento das "luzes" estrangeiras. As inovações the surgeriam como ameaça ao trono. Daí a política da realeza - dúbia e oscilatória - ser concordante com seu ordenamento de feição "feudatária". A mudança apregoada pelos teóricos espanhois não dispunha de originalidade, por não contar com pensadores fidedígnos e por estar a Coroa ainda "amarrada" a valores da ordem medieval. Os assessores do trono bebiam em fonte alheia. Toda a "elite" era afrancesada, inclusive o douto Jovellanos, bem como as demais "estrelas" da constelação "iluminada" pelas luzes alienígenas (48).

(46). - Veja-se nossa tese, O Real Consulado de Caracas (1793-1810), págs. 131 e segs. Caracas, 1971. Academia Nacional de la Historia. Vide ainda, Capdequi (J.M. Ots), El siglo XVIII español en America. El gobierno politico del Nuevo Reino de Granada. Aporte documental, págs. 143 e segs. México, 1945; Diccionario e Historia de España, t. II, págs. 22 e segs. Madrid, 1952.

(47). - Vide nossa comunicação apresentada ao $4^{\circ}$ Congresso Internacional de História da América, realizado em Buenos Aires no período de 5 a 12 de outubro de 1966 - El Real Consulado de Caracas, factor económico de la Independência de Venezuela, in tomo VI, págs. 287 a 298 . Buenos Aires, 1966.

(48). - Cf. Peñalver (A.), Modernidad tradicional en el pensamiento de Jovellanos, págs. 10 e segs. Sevilla, 1953; Artola (N.), Vida y pensamiento de Don Gaspar Melchor de Jovellanos, págs. 73 e segs. Madrid, 1956; Sarrailh (Jean), L'Espagna eclairé de la seconde moitié du XVIII siècle, págs. 102 e segs. Paris, 1954; La crise religieuse en Espagne à la fin du XVIII siècle, págs. 
A orientação francófila jungia a Espanha à França, fato demonstrado no sistema das alianças na Guerra dos Sete Anos (1756-1763), quando a prosperidade das colônias francesas da América Setentrional levou a Inglaterra a investir contra o Canadá. Ao mesmo tempo a guerra marítima desencadeada por George II animou Luis XV, em 1761, a promover o célebre "Pacto de Família", transformando-se a guerra continental numa guerra colonial, sobretudo. O primeiro ministro de Luis XV, Choisseul, enxergaria as Indias Ocidentais de Espanha como um admiravel empório fornecedor de produtos comerciáveis. Substituir a Grã-Bretanha dos Georges no comércio americano era um dos anseios do capitalismo francês, cujos artigos industriais concorriam com seus congêneres britânicos. A Inglaterra contaria com a conjuntura internacional criada pelo tratado de Utrechet, em 1713, que pôs fim à Guerra da Sucessão da Espanha, e pelo qual Filipe $V$ foi reconhecido com a condição, porem, de que nunca as Coroas de França e de Espanha viessem a reunir-se. O governo de Londres esquecera-se que o "equilíbrio" europeu mudara logo no decorrer dos anos subsequentes.

O capitalismo britânico tinha interesse em continuar a introduzir produtos manufaturados em Espanha, cuja forma de pagamento poderiam ser os vinhos e os azeites, bem como certas mercês do tráfico americano. Mas as discórdias entre a França e a Inglaterra, por ocasião da nova conjuntura oriunda da independência dos Estados Unidos, em 1776, procuraram envolver o governo de Madri. O bloco franco-britânico, então antagônico, disputava a "mina" americana espanhola.

Carlos III hesitava entre a França e a Inglaterra. A "desgraciada entrada en las guerras" era malefício imposto pela conjuntura continental e pelo regime de exploração ultramarina. A Espanha tinha um rico patrimônio americano a defender da cobiça de seus próprios "aliados". $\mathrm{Na}$ trama das relações diplomáticas figurava, em destaque, o comércio indiano senhoreado pelos Borbons espanhois.

Já se acusara a "Ilustração" de regalismo. A expulsão dos jesuitas respondera ao espírito da filosofia política do despotismo esclarecido. Com isso desmanchara-se a base do império espanhol pela anulação das tendências tradicionais. Todavia, a monarquia era centralista e fiel vassala da Santa Sé. Cristianismo católico e "Iluminismo" eram destoantes. A catolicidade era uma das singularidades do trono. Porisso a "Ilustração" espanhola gerou-se desarmônica com a

73 e segs. Oxford, 1951; Nerr (Richard), The Eighteenth-Century Revolution in Spain, págs. 58 e segs. Princenten, 1958. 
religiosidade da realeza e com os valores nacionais. A fé católica destoava da fé racionalista das "luzes".

Não obstante, Carlos III mostrou-se disposto em descativar o tráfico americano, desobstruindo-o de seus entraves monopolistas. Liberalizar, sim, mas conforme a realidade espanhola. Ia longe o sistema colonial dos Habsburgos assente numa concepção estritamente mercantilista. Semelhante sistema, primeiro ensaio, revelara-se deficitário por não impedir a fuga de metais preciosos para o estrangeiro, malefício oriundo da falta de uma estrutura industrial metropolitana, suficientemente capacitada para fornecer ao ultramar as manufaturas imprescindíveis .

O regime de frotas e feiras, ordenado pelo referido Diploma de 5 de abril de 1720 , não agradou à burguesia periférica do reino, cujos anseios figuravam numa proporção mais ampla. O desarranjo do sistema, notadamente a grita dos Consulados de Lima e México devido às irregularidades operacionais das frotas e dos baixos preços alcançados pelas mercadorias nas feiras (49), demonstrou o malogro do expediente. Tampouco as Companhias solucionaram as aspirações do mercantilismo do Cantábrico e do Mediterrâneo, embora atenuassem o descontentamento da Catalunha e do País Basco, regiões beneficiadas pelas Companhias de Barcelona e Caracas. Mas os demais portos haviam sido marginalizados.

O estágio da economia e a atitude da Coroa em relação aos problemas do setor privado requeriam algumas reflexões. O diálogo do governo com os empresários coloniais da periferia marítima foi no sentido de ouvir reivindicações e atende-las ou não. A conjuntura havia mudado em toda a parte. O setor privado descontente só tinha uma pretensão: liberdade para operar. Os "furtivos e ilícitos tratos" geravam inconvenientes que se manifestavam em todos os setores da economia nacional, com enormes sangrias na poupança da realeza.

Os interesses do alto comércio gaditano e os de Lima e México eram conflitantes, bem como todas suas conveniências eram antagônicas às "liberdades" desejadas pelo mercantilismo periférico do reino e do ultramar. Os empresários americanos queriam a ruptura do sistema de frotas e feiras, que há muito se revelava deficitário. Os próprios "navios de registro", complementos das frotas de Nueva España e Panamá, instituidos para as regiōes mais distanciadas e não servidas pelos comboios regulares, não satisfaziam a burguesia do Mediterrâneo e do País Basco, tampouco agradavam o trato das Ilhas de

(49). - Cf. Paz-Seldán (M. Moreyra), Estudios sobre él tráfico maritimo en la época colonial, págs. 84 e segs. Lima, 1944; Diaz (José J. Real), Las feiras de Jalapa, págs. 87 e segs. Sevilha, 1959. 
Barlovento, Venezuela, Prata e Chile, onde o contrabando praticado pelos atravessadores nacionais e estrangeiros sobressaia. A participação legal da burguesia periférica do reino através das Companhias de Caracas e Barcelona, embora constituisse uma conquista das novas forças socio-econômicas peninsulares, era apenas mais uma experiência - ensaio no processo de transição de um monopólio rígido para outro mais flexivel e aperfeiçoado.

A mencionada Ordenança de 5 de abril de 1720 seguiu-se a Real Cédula de 21 de janeiro de 1735, que reduziu a frota de Nueva España a oito navios e eliminou a do Panamá - "de los Galeones" -, bem como prescreveu navios de "registro" para aprovisionar as praças de Cartagena e Portobelo (50). Semelhante disposição régia desagradou os negociantes de Lima e México. Em contrapartida foi bem recebida pelo Consulado de Cadiz e pelo "cuerpo de comercio de Sevilla" que lhe era "associado". Posteriormente, pela Real Ordem de 20 de junho de 1749, os empresários americanos residentes e domiciliados no Perú e Nueva España obtiveram "liberdade" para suas transações (51).

As medidas fixadas pela Coroa patentearam a revisão nos métodos de exploração do tráfico colonial, bem como os progressivos privilégios concedidos pelo poder público aos comerciantes americanos que há muito reclamavam contra o regime de frotas e feiras, que ape nas favorecia o monopólio gaditano, embora já abalado pela instituição das Companhias de Caracas e Barcelona.

Os empreendimento da Catalunha e do País Basco no trato direto com a América, através da experiência das Companhias, constituem um triunfo das agremiações dos portos marítimos do reino. De igual modo a referida Ordem régia de 20 de junho de 1749 representa uma façanha dos comerciantes crioulos descontentes. Ambas forças - empresários da Espanha periférica e da América - conjugadas abririam brechas no concretado sistema tradicional. Os navios de "registro" e as Companhias - ensaios de um processo inovador - desferiram profundo golpe no ordenamento do mercantilismo da dinastia anterior. Contribuiram para o fomento do comércio e da navegação entre Espanha e suas Indias Ocidentais. O sistema dos "registros" para o Prata e Chile - regiões mais distantes e menos aquinhoadas pelos favores da realeza, e onde era mais franco o contrabando - foi altamente afortunado. Semelhantemente foi deveras propício, pelos rombos abertos no monopólio de Cadiz, o exercício das Companhias no Caribe insular e continental.

(50). - R.C., in Levens, Docs. cit., t. V, págs. 115 e segs.

(51). - Ibidem. 
Com a subida ao poder da equipe presidida pelo Conde de Aranda ordenou-se uma profunda mudança estrutural. Uma Junta reunida em 14 de fevereiro de 1765 decidiu extinguir ambos monopólios o gaditano e o das Companhias - concedendo-lhes um prazo de dois anos para a liquidação de seus fundos. Meses depois, o Decreto de 16 de outubro, admitiu as ilhas de Cuba, Santo Domingo, Puerto Rico, Margarita e Trinidad no trânsito direto com determinados portos peninsulares do Mediterrâneo (Málaga, Alicante, Cartagena e Barcelona) e do Cantábrico (La Coruña, Gijón e Santander), alem dos tradicionais de Sevilla e Cadiz (52).

Ainda em 1765 Carlos III criou o Correio Marítimo - entidade de direito público - que converteu La Coruña no porto oficial de partida e arribada das fragatas-correio da Coroa, saindo uma cada mês para a América Setentrional - com Caixa Postal em Havana - e outra cada dois meses, com Caixa Postal em Montevideo (52).

A partir daí a situação começou a mudar, introduzindo-se preceitos moralizadores que passaram a orientar a elaboração e a execução do novo sistema colonial espanhol. Entre as normas legais saneadoras figuram em destaque o "Reglamento y aranceles reales para el Comercio libre de España e Indias", publicado em Madri, a 12 de outubro de 1778, por Pedro Marin, editor oficial (54), em cuja redação desempenhou papel relevante o "contador general" Don Tomás Ortiz de Landázuri com seus pareceres (45).

(52). - Cf. Decreto y Real Instrucción de 16 de outubro de 1765 , (Idem, págs. 197). Vide ainda - Casado (V.R.), Comentarios al Decreto y Real Instrucción de 1765, regulando las relaciones comerciales de España e Indias, in "Anuário de Historia del Derecho Español", t. XIII, págs. 100 e segs. Madrid, 1936.

(53). - Já anteriormente a Coroa havia delineado a instituição. Vejase o "Reglamento provisional del correo-maritimo de España a sus Indias Occidentales", assinado pelo Marquês de Grimaldi e datado de San Ildefonso a 24 de agôsto de 1764, in "Archivo General de Indias", Seccion 5a, Indiferente General, legajo $n^{\circ} 1586$. Uma tese de doutoramento sôb:e o Correio Marítimo elaborada sob nossa orientação - a de Manoel Lelo Bellotto -, já defendida e aprovada com distinção, acha-se no prelo em São Paulo.

(54). - No "Archivo General de Indías" acha-se um exemplar. Encontra-se ainda na obra de Antonio Javier Perez y Lopez - Theatro de la legislación universal de España e Indias, por orden cronologica de sus cuerpos $y$ decisiones recopiladas, t. VII, págs. 294 e segs. Madrid, 1791-1798. Veja-se ainda o estudo de José Muñoz Perez, La publicación del Reglamento de Comercio Libre a Indias de 1778. Separata do "Anuário de Estudios Americanos", t. págs. 615 e segs. Sevilha, 1947. Importa ver, ademais, no "Archivo General de Indias" - Indiferente General, legajo $n^{\circ} 2409$ - informatives papeis atinentes.

(55). - Cf. Informe del Contador Ortiz de Landázuri, de 6 de dezembro de 1776, in "Archivo General de Indias", Indiferente General, legajo $\mathrm{n}^{\text {? }}$ 2409. 
O Regulamento de 1778, que instituiu o "comércio livre", foi o "golpe de morte" desperido pela "Ilustração" de Carlos III no mercantilismo tradicional. Constitui uma genuina codificação, visto que no "Reglamento y aranceles" se agrupam as diversas disposições ou regras legais acerca do tráfico americano. Trata-se, em realidade, duma sistematização de princípios relativos à matéria que faz objeto de um ramo do Direito - o Comercial Marítimo - ordenado para o trato "libre y protegido entre Españoles Europeos y Americanos", único meio de "restablecer en mis Dominios la Agricultura, la Industria, y la Población a sua antiguo vigor" (56).

A Coroa demonstrou querer não apenas o desenvolvimento do seu patrimônio, mas construir uma sociedade econômicamente "descentralizada" e politicamente "aberta". A estratégia utilizada para atingir estes objetivos foi a codificação de 12 de outubro de 1778 que consubstanciou o êxito da Espanha periférica, identificando os seus anseios com as aspirações do empresariado crioulo.

Rompeu-se, afinal, o monopólio gaditano com a entrada legal no trânsito ultramarino dos portos seguintes: Palma em Mallorca, e Santa Cruz de Tenerife nas Canárias, e os da Espanha periférica - Málaga, Almería, Cartagena, Alicante, Alfaques de Tortosa, Barcelona, Santander, Gijón, El Ferrol e La Coruña. Completou-se o rol com us postos americanos que se seguem: Santo Domingo e Monte-Christi, "en la Isla Española", Santiago, Trinidad, Batabano de Havana, na ilha de Cuba; San Juan, na ilha de Puerto Rico; Margarita e Trinidad, nas respectivas ilhas; Campeche, Omoa e Santo Thomás de Castilla, "en el Reyno de Goatemala"; Chagre, Portobelo, Cartagena, Santa Marta, Rio de la Hacha, "en el de Santa Fé y Tierra Firme (57); Montevideo e Buenos Aires, "en el de la Plata"; Concepcion e Valparaíso "en el Reyno de Chile"; Arica, Callao e Guayaquil, "en el Reyno del Peru y Costas de la Mar del Sur" (48). Aos portos de Palma e Santa Cruz de Tenerife restrigiu-se o embarque aos gêneros próprios das ilhas (59).

A realeza sem renunciar ao "dirigismo" instaurou a "liberdade" do trato entre Espanha e América. A inovação estrutural exercendo internamente uma influência decisiva sobre o carater da propriedade,

(56). - "he mandado formar un Reglamento completo que contenga todos los puntos de las anteriores concesiones no revocados en esta" (Cf. Reglamentos y aranceles ...., págs. 1 e segs).

(57) . - "exceptuando por ahora los de Venezuela, Cumaná, Guyana, y Maracaybo concedidos a la Compañia de Caracas sin privilegio exclusivo" (Idem, art. 5, pág. 9).

(58). - Idem, págs. 8 e segs.

(59). - "a menos que vengan sus Embarcaciones a toma-los en alguno de los Puertos habilitados de España" (Idem, art. 4ọ, pág. 8). 
sobre a organização empresarial, alterando a composição das forças dominantes, repercutia sobremaneira em todos os setores da vida na economia, na sociedade e na política - no reino e no ultramar. O novo sistema colonial foi fator de renovadas possibilidades de expansão capitalista. A experiência elaborada e executada a partir de 1778 exigia um giro intercolonial ativo e meios transoceânicos de negociação mercantil. A uma economia "estancada" opunha-se, então, uma inteiramente nova cujas próprias condições de crescimento the advinham do trânsito à distância acionado pela diversificação de produtos altamente comerciáveis: açucar e tabaco de Havana; cacau e anil de la Guayra; resinas, ervas medicinais, gomas, madeiras de construção e tintoriais de Campeche, Chagre, Santo Thomás de Castilla, Trinidad, Margarita, Batabano, Santiago de Cuba e San Juan de Puerto Rico; prata de Veracruz (60) e couros de Montevideu e Buenos Aires (61).

As quantidades apuradas no tráfico comprovam o fomento da economia colonial, sobretudo, integrando-se a partir de então nas grandes linhas internacionais de troca. Graças a isso a sociedade crioula transformou-se profundamente. O trânsito mercantil deixou de agrupar-se à volta dos "eixos" tradicionais para adentrar-se na urdidura capitalística do século "iluminado". No novo sistema colonial os espanhois da América e os emigrados da Península encontrariam em si próprios a mais clara expressão das suas exigências momentâneas.

A sociedade que se ia estruturando no ultramar principiava a reunir as condições de desenvolvimento - a acumulação social de riqueza e o trabalho livre. Aquela fazia-se ainda quase unicamente pela especulação do capital comercial. E o trabalho livre encontrava-se tanto no campo como na cidade a marcar já a fase que se abria na evolução do comportamento crioulo.

O novo sistema colonial consubstancia dupla vitória: a da Espanha periférica no embate pela ruptura do centralismo monopolista gaditano, bem como a dos crioulos americanos sobre o empresariado peninsular. Ambas acham-se urdidas na mesma teia do processo de desenvolvimento do tráfico ultramarino acionado, em grande parte, pela conjuntura internacional e pela emigração de empresários coloniais procedentes do reino - notadamente catalães e bascos - exigências da América que se mostrava disposta a quebrar as amarras que ainda a prendiam à Europa.

(60). - Cf. Avelino (Yvone Dias), A prata de Veracruz na época do "Comércio Livre" (1778-1787). Pugliesi (Haydée Marquiafave), A prata mexicana no circuito atlântico (1788-1790). Ambas teses de doutoramento, defendidas em São Paulo e Franca, respectivamente em 1972 e 1974, acham-se no prelo. e segs.

(61). - Veja-se nossa citada tese, $O$ comércio livre..., vol. I, págs. 183 
Esse clima de sadio pragmatismo passou tambem a reinar na administração pública venezuelana e nos anseios regionais - elos duma mesma cadeia. Os caraqueños viviam então as aspirações do século das "luzes". Os ideais inovadores chegariam igualmente à Venezuela, não obstante a demora dos "navios da Ilustração". O revigoramento do tráfico foi enorme, com efeitos imediatos nos diferentes setores da produção e da circulação. Com a acumulação de grandes fortunas privadas acentuou-se o domínio dos comerciantes e dos agricultores crioulos sobre o médio mercador e sobre o artesanato. Nessa crescente subjugação do pequeno produtor ao alto comércio e aos capitais agrários encontra-se a força que alterou as condições de trabalho e as correntes do tráfico.

No ocaso colonial a sociedade venezuelana já se mostrava bem estruturada. O povo diferenciava-se rapidamente no processo de desenvolvimento da burguesia dos portos marítimos. O prestígio adquirido pelos comerciantes no giro entre a orla litorânea e as regiōes agricolas da hinterlândia, onde dominavam os grandes senhorios da terra, crescia no trato transoceânico.

A desigualdade vinha, é certo, dos tempos heroicos da conquista da terra e de sua incorporação ao patrimônio da realeza. Mas os grupos sociais já se haviam composto no governo de Carlos III com os diferentes desníveis oriundos da colonização: brancos - espanhóis peninsulares e americanos; negros submetidos ao regime de trabalho escravo; índios e mestiços de branco e negro; de branco e índio e "zambos" de índio e negro, alem de outros cruzamentos transversos. A população compunha-se, afinal, de três grandes agrupamentos sociais consoante suas condições econômicas, seu estado cultural e seus direitos civis e políticos: a oligarquia crioula detentora do poder nas cidades e nos campos; a enorme massa dos pardos livres composta dos mestiçados e sem condições de poupança; e os escravos negros e nativos (62).

A oposição dos grupos sociais manifestou-se intensamente no decurso do século XVIII, quando os desníveis alcançaram maior amplitude. Na segunda metade da centúria, sobretudo, os crioulos pretenderam uma maior consideração, tanto dos pardos como dos peninsulares espanhois. Anteriormente à instituição da Capitania General, em 1777 , os altos cargos públicos eram entregues a reinois favoritos do

(62) - - Cf. Moron (Guillermo), Historia de Venezuuela, págs. 150 e segs. Caracas, 1961; Chuecos (Héctor García), Estudios de Historia Colonial Venezoelana, págs. 61 e segs. Caracas, 1937; Vila (Mar-Aurelio), Geografia de Venezuela, págs. 152 e segs. Caracas, 1957; Figueroa (F. Brito), Ensayos de Historia Social Venezoelana, págs. 13 e segs Caracas, 1960; La estructura social y demográfica de Venezuela Colonial, págs. 7 e segs. Caracas, 1961. 
trono e aconchegados a ministras de Estado. Os crioulos - brancos venezuelanos - estavam geralmente marginados, não obstante seren fieis vassalos da Coroa.

O predomínio político dos peninsulares minguou com a criação da Capitania General, cuja administração identificou-se cada vez mais com as conveniências regionais. Constituindo poderosa força socioeconômica, os crioulos foram obtendo determinadas prerrogativas da realeza "ilustrada" que lhes possibilitou erigirem-se numa aristocracia colonial estruturada no comércio e na agricultura (63).

$\mathrm{Na}$ centúria da "luzes", o reconhecimento da conveniência de instituir-se na Capital da Província, em 1721, uma "Real y Pontifícia Universidad" (64); a investida de Juan Francisco de León contra a Companhia Guipuzcoana, em 1749 (65); a visita "del Obispo de Puerto Rico a la región oriental de Venezuela", no ano de 1760 (66); a Real Cédula de 8 de setembro de 1777, dada por Carlos III em San Ildefonso, que instaurou a Capitania General (67); o estabelecimento da "Intendencia de Ejército y Real Sacienda" (68), bem como a cria-

(63). - Farías (E. Arcila), El siglo ilustrado en America. Reformas economicas del siglo XVIII en Nueva España. Contribución al estudio de las instituciones hispanoamericanas, págs. 255 e segs. Caracas, 1955.

(64). - Cf. Petição a Filipe V, datada de Caracas em 2 de fevereiro de 1721, dos "Alcaides Gobernadores de Caracas, don Alejandro Blanco y don Juan de Bolivar Villegas", in Chuecos (Hector Garcia), Historía Documental de Venezuela, págs. 3 e segs. Caracas, 1957.

(65). - "Carta del Gobernador y Capitan don Luis Francisco Castellanos al Rey", datada de La Guaira em 10 de maio de 1749 (Idem, págs. 23 e segs.).

(66). - Cf. "Relación pa:a el Rey" (Idem, págs. 146 e segs.).

(67) . - Em virtude da Real Cédula de 8 de setembro de 1777, que instituiu a Capitanía General, incorporaram-se à "Gobernación de Venezuela" as Províncias de Cumana, Guyana e Maracaíbo, e as ilhas adjacentes de Margaríta e Trinidad, constituindo um todo orgânico, base da "Nación Venezoelana". Até então, as Províncias que a Coroa havia criado no território dependeram, primeiro, da Audiência de Santo Domingos e, depois, do "virreinato" de Santa Fé (Cf. Antologia Documental de Venezuela..., págs. 117 e segs.).

(68). - Veja-se a Real Ordem de 8 de maio de 1781 (Idem, págs. 114 e segs.). Vide ainda: - Sucre (Reyes José), Le systema Colonial Espagnol dans l'ancien Venezuela, págs. 51 e segs. Paris. 1939; Cabrera (J. Gonzales), Caracas y su Regimen Municipal, págs. 39 e segs. Caracas, 1941; Pierson (W.W.), La Intendencia de Venezuela en el Régime Colonial, in Boletin de la Academia Nacional de la Historia", págs. 73 e segs. Caracas, 1941; Eciso (G.M. de Perez), La intendencia en España y en Ameríca, págs, 36 e segs. Caracas, 1966. 
ção da Audiência (69) de Caracas (70), marcam nítidas fases da evolução orgânica da colônia. Comprovam sobejamente a marcha que os crioulos seguiram no caminho de sua libertação. Foi gigantesco o desafio da Capitania General, testemunho de que os venezuelanos estavam conscientes da importância da sua atuação no processo de desenvolvimento. A Venezuela despertava, afinal, do torpor econômico em que a tinha lançado o monopólio da Guipuzcoana (71) para atingir o ponto crítico de passagem a um nivel que reclamaria, seguidamente às reformas estruturais no âmbito da economia, sua maioridade política na abertura da centúria subsequente. Suas classes avançadas, fielmente representadas pelas grandes famílias crioulas, julgavam-se capacitadas para eliminar os obstáculos que ainda entravavam a sua evolução.

Setores da economia regional vinham de há muito pondo certas questões. O "comércio livre" instituido em 1778 entre Espanha e América não beneficiaria a orla periférica dos portos marítimos da Capitania recem-nascida; tampouco as terras e águas da sua hinterlândia. A Venezuela figurava ainda na jurisdição da Companhia Guipuzcoana, cujo exclusivismo recuava a 1728. Daí as investidas contra o monopólio dos empresários do País Basco (72). O tráfico "libre y protegido" exerceria sobre o empresariado crioulo aquela mesma aspiração que fora na Espanha periférica e nos portos marítimos americanos, favorecida pelo trono "iluminado", a mola que vinha acionando o novo sistema colonial.

(69). - Constituem as "Audiências" organismos para a administração da Justiça. Foram estruturadas com "cue:pos colegidos con un area territorial de competencia, correspondiente a un reino o provincia, y una esfera de actuación propía, integrada por unas facultades de naturaleza regia o suprema" (Cf. Diccionário de História de España, t. I, pág. 320, cit. ed.).

(70). - Cf. 'Real Ordem para su inteligencia y gobierno", datada de Aranjuez em 13 de julho de 1786, in cit., Antología Documental de Venezuela, págs. 119 e segs.

(71). - Cf. Basterra (Ramon de), Una Empresa del Siglo XVIII. Los navios de la ilustración. Real Compañia Guipuzcoana de Caracas y su influencia en los destinos de America, págs. 269 e segs. Caracas, 1954. A Real Cédula da empresa, assinada por Don Joséph Patiño, ministro de Filipe V, datada de 25 de setembro de 1728, esta impressa e acha-se no "Archivo General de Indias" e no "Archivo General de la Nación", em Caracas. Encontra-se ainda na citada Antologia Documental de Venezuela, págs. 93-101.

(72). - "Expediente y autos sobre las solicitudes de Don Juan F:ancisco León, apoderado de varios vecinos de Caracas, sobre perjuícios causados por la Compañia Guipuzcoana", in "Archivo General de Indias" - legajo $n^{\circ}$ 937; "autos y documentos sobre la propiedad de los terrenos y edificios de la Compañia Guipuzcoana" ( $I$ dem, legajo n $n^{\circ}$ 938); "Expedientes sobre la conjuración y levantamiento de la provincia y causa contra Don Francisco León y demás reos" (Idem, legajos n's. 418 a 421). Veja-se ainda — Padzon (F. Morales), Rebelión contra la Compañia de Caracas. Sevilha, 1955. 
Extinto o giro da Guipuzcoana em 1784 e superada a ingerência da Companhia das Filipinas (73), sua sucessora, toda a cadeia do trato foi profundamente alterada. Em 1737 os portos da Venezuela, notadamente La Guaira, já se encontram no rol dos "legajos" referentes ao "Comércio livre". guardados no "Archivo General de Indias". E nos anos que se seguiram, as carregações regionais engrossaram sobremaneira as correntes do comércio entre a Capitania e a Metrópole, estatística que comprova a superação (74). A Venezuela, solta das amarras do monopólio, saiu da "estagnação" econômica gerada pelo mercantilismo tradicional. Seus portos marítimos, alargados até às margens dos seus congêneres do reino, através da "liberdade" do trânsito oceânico, adquiriram aspecto inteiramente novo (75).

O estabelecimento do novo sistema colonial induziu a Venezuela à sua transformação orgânica, de conformidade com os anseios crioulos e consoante suas possibilidades geográficas e econômicas. Com a Real Cédula de Carlos III de 8 de setembro de 1777, que instituiu a Capitania General, criou-se uma unidade política regional. E no ano seguinte a promulgação do Regulamento de 12 de outubro, ordenando o "comércio livre", ecoou em todas as "Gobernaciones", gerando no "espírito nacional" aquelas mesmas tendências que vimos esboçaremse no reino: abolição das restrições que ainda entravavam a "livre" comunicação.

As duas instituições - criação da Capitania General e estabelecimento do "comércio livre" - estruturadas no reformismo de Carlos III quase a um só tempo, metamorfosearam a Venezuela, até então regionalmente dividida e antagônica, numa Venezuela unida pelos mesmos interesses. A Capitania General, exercendo influência decisiva sobre as diferentes Províncias, agregou num só bloco, com conveniências a defender e a legitimar, o que anteriormente a 1777 era composto pelas resistências e antagonismos das "Gobernaciones" de Caracas, Cumana, Guyana, Margarita, Trinidad e Maracaibo. A unidade política da Capitania repercutiu enormemente na ordem social e econômica da colônia .

As diligências e prerrogativas agrupavam-se então à volta dos crioulos, representados pelos poderosos agricultores e pelo alto co-

(73). - Sobre a efêmera atuação da empresa na Venezuela, veja-se o estudo de M.L. Diaz-Trechuelo Spinola, La Real Compañia de Filipinas. Sevilha. 1965 .

(74). - A.G.L. - Indiferente General, legajos n's. 2409, 2410, 2441 a 2446 . As quantidades acham-se apuradas em nossa tese $-O$ Real Consulado de Caracas (1793-1810), II vol., págs. 280 e segs. São Paulo, 1968 (A obra acha-se no prelo, em Caracas).

(75). - Ibidem. 
mércio - naturais continuadores dos herois do tempo da conquista e da colonização. As reformas estruturais do tráfico colonial precipitariam a evolução política, social e econômica da Capitania, cuja sociedade se arranjara em "classes" profundamente diferenciadas - brancos crioulos e espanhois peninsulares, pardos, índios e negros. Os índios eram "encomendados". Os negros eram escravos. Esse sentido discriminativo que caracterizou a colônia, acentuado pelo absolutismo da realeza e pelo sistema de exploração do tráfico, condicionou o movimento da Independência na abertura do século XIX (76).

O monópolio exercido pelo mercantilismo tradicional era uma afronta para os "terratenientes" crioulos. Os baixos preços dos gênerós regionais e a alta das importações do reino eram censurados pelos "mantuanos", senhorios dos campos agricultados (77). A literatura da "Ilustração" começava a ser lida na colônia. A liberdade já não era para a "elite iluminada" uma premissa religiosa, senão uma conclusão do pensamento amadurecido na leitura dos escritos de exportação alienígena (78). A doutrinação do liberalismo político, inspiradora da Revolução Francesa, bem como os ideais que nortearam a Independência dos Estados Unidos, atingiram tambem as aspirações dos venezuelanos, cujos interesses eram cada vez mais adversos às conveniências do empresariado peninsular e da monarquia centralizada.

Carlos III falecera aos 14 de dezembro de 1788. Sucedeu-lhe seu filho Carlos IV, com quarenta anos de idade e casado com sua prima Maria Luiza de Parma, da qual já haviam nascido o príncipe Fernando e o infante Carlos Isidro (79). Vivia-se então uma época efervescente. A "Declaración de los derechos del hombre", em agosto de 1788, sobressaltou a Corte de Madri. A maior preocupação do soberano era a salvaguarda do trono. Mas os acontecimentos na Europa favoreciam a posição dos crioulos americanos. Nesse contexto é que se ordenou uma nova instituição venezuelana para o fomento da agricultura, do comércio e das vias de comunicação: o Consulado de Caracas.

A população da Capitania havia crescido, inclusive pela emigração do reino. Em 1767 o número de habitantes não ia alem de 184 mil, ano em que na cidade de Caracas viviam 26.340 almas e em La

(76). - "Tres siglos de dictadura y exploración fueran suficientes para estructurar las bases de la revolución independentista". Ortiz (Rafael Gallegos), La historia, politica de Venezuela. De Cipriano Castro a Perez Jimenez, pág. 8, Caracas, 1960).

(77). - "descendientes de conquistadores pero nacidos en nuestro país, eran por herencia los dueños de las tierras y de los frutos" (Idem, pág. 27).

(78). - "Libros que nos hablaban de la reivindicación de los fueros racionales del nombre" (Idem, pág. 34).

(79). - Cf. Zabalay Lera (Pio), op. cit., págs. 62 e segs. 
Guaira, o principal porto, 3.527 (80) . Em 1801, a população venezuelana já se elevava a 728 mil habitantes $(81)$. O crescimento era a um só tempo agente e consequência duma produção de gêneros oriundos da agricultura comerciavel. O fomento do giro capitalístico levou o empresariado à montagem duma "marinha mercante" crioula (82) cujos navios operavam dividindo-se os lucros do tráfico em três partes iguais a favor de seu dono, do comerciante e do produtor dos frutos (83). Semelhante prática de direito comercial marítimo aconchegava os elementos humanos do trato - agricultores, criadores, comerciantes e armadores - numa "parceria" de responsabilidade solidária, agregado que retratava as ansiedades da colônia.

A partir de 28 de fevereiro de 1789 os portos venezuelanos entraram no "comércio livre" (84) - cinco anos depois de extinta a Guipuzcoana. A odiada Companhia nunca conseguira tolher o contrabando (85) e ela própria o praticava fora de sua jurisdição (86) malefícios amargados pela Coroa e pelos crioulos produtores. A riqueza agropecuária dependia do mercado consumidor externo. Por caminhos diversos, através dos portos da Capitania ou dos seus congêneres do reino, bem como pelas "escápulas" de Nueva España (87) e de certas charneiras do Caribe insular e continental, escoavam os frutos regionais.

O "nacionalismo" dos "terratenientes criollos" impressionou Depons. Os venezuelanos orgulhavam-se de haver nascido na América, sua "pátria natural", vendo nos espanhois peninsulares a ganância e a miséria do reino (88). ACapitania, pelas reivindicações políticas e

(80). - Moreno (A. Arellano), Orígenes de la economia venezoelana, pág. 129. Caracas-Madrid, 1960.

(81). - Depons (F.R. Joseph), Viaje a la parte oriental de tierra firme en la America Meridional, t. I, pág. 75. Caracas, 1960.

(82). - Vargas (F. Alexandro), Historia Naval de Venezuela, t. I, págs. 52 e segs. Caracas, 1956.

(83). - Moreno (A. Arellano), op. cit., pág. 172.

(84). - Anteriormente a essa data não encontramos elementos seguros da entrada dos portos venezuelanos no giro do "comercio livre".

(85). - A partir de 1752 "el contrabando... tomó un vigor poco corriente, y ni la Corona ni la Compañia pudieron tomar medidas drásticas para evitarle". [Cf. Figueros (Federico Brito), Ensayos de Histora Social Venezoelana, pág. 164. Caracas, 19601.

(86). - "ella misma practicaba al contrabando" ... (idem).

(87). - Cf. Farias (Eduardo Arcila), Comercio entre Venezuela y Mexico en los siglos XVII y XVIII, págs. 37 e segs. Mexico, 1950.

(88). - - "juzgan que no hay país superior al suyo y por la avidez que traen los Españoles de la metrópoli, piensa que viven en la comarca más afortunado de la tierra. nunca toman cuenta de la dulzura del clima ni las p:oducciones de Europa, solo ven la miseria de los que salen de alla" [Cf. Depons (F), Viaje... pág. 79, cit. ed.1. 
econômicas de suas forças sociais ascendentes, abriria os caminhos à instituição dos consulados modernos no Novo Mundo - primeira experiência de govêrno econômico "nacional" - enorme torcedura no sistema colonial do reinado de Carlos IV. O construtivo debater de idéias irmanou correntes de pensamento, coadunou forças e uniu os interesses dos "hacendados" às conveniências do alto comércio local, aperfeiçoando conhecimentos num amplo alargar de horizontes.

Em 31 de julho de 1786, por Real Cédula de Carlos III, instituiu-se a Audiência de Caracas com jurisdição em todas as Províncias da Capitania da Venezuela, evitando-se assim que todo o contencioso continuasse tramitando em Santo Domingo ou em Santa Fé (89). A Real Audiência funcionava como Tribunal de Justiça. Normalmente conhecia e julgava a controvérsia em primeira instância. Mas podia tambem decidir em segundo grau "fallos" de tribunais inferiores. Das sentenças da Audiência cabiam recursos ao "Consejo de Indias", instância superior. Com o estabelecimento da Audiência de Caracas com jurisdição sobre Cumaná, Maracaibo, Guazeana, Ilhas de Trinidad e Margarita - reafirmou-se a unidade "nacional e patriótica" venezuelana (90).

A Venezuela era, então, um dos principais "eixos" do Caribe e do giro transoceânico. A Capitania era uma porta "aberta" para o mundo capitalista. Sua abastança exportavel era um modo permanente de aquisição de riqueza social. Todas as reformas estruturais, que culminariam com a instituição consular, figuram num mesmo processo de reivindicação "nacional e patriótica", embora com aspectos próprios que as caracterizou. Nessa marcha ascendente apercebem-se, cada vez mais claramente, os novos fundamentos em que se construia a sociedade venezuelana. Enquanto evoluiu no sentido da sua emancipação, a Capitania realizou as transformações sociais, políticas e econômicas adequadas ao seu desenvolvimento. Nada-mais resistiria a essa força crescente que encontraria a mais clara expressão das suas exigências no Consulado de Caracas, instituição criada por Real Cédula de Carlos IV, expedida em Aranjuez em 3 de junho de 1793, para o fomento da agricultura, do comércio e das vias de comunicação (91).

(89). - Real Cédula, datada de Aranjuez em 31 de julho de 1786, da criação da Audiência de Caracas, in Antologia Documental. . .,págs. 119 e segs.

(90) . - A Real Audiência foi instalada em 19 de julho de 1787. Compunha-se de um "regante", três "cidores", un "fiscal" e un presidente o capitán general da Capitania" (Cf. "Personal de la Audiêncía de Caracas". Idem, págs. 120 e segs.).

(91. - Veja-se a "Real Cédula de eraccion del Consulado de Caracas, expedida em Aranjuez a III de junio de MDCCCIII. Madrid, MDCCXIII, En la Oficina de Don Benito Cano", in "Archivo General de la Nación", em Caracas. Acha-se ainda publicada in E. Arcila Farias (El Real Consulado de Caracas. Introducción y compilación ,págs. 57 e segs. Caracas, 1957), Santos 
Insensato se nos afigura vincular a idéia do estabelecimento do Consulado a uma só pessoa. O projeto deve-se a um movimento crioulo que vinha de longe. Francisco de Saavedra, Intendente de $\mathrm{Ca}$ racas, com sua adesão à "causa nacional", apenas afirmou no plano político os anseios dos agricultores e comerciantes venezuelanos.

O comércio da colônia necessitava dum Corpo autônomo para julgamento de suas lides. Impunha-se a criação de um Tribunal de Justiça Mercantil para conhecer e resolver as pendências oriundas da prática de atos de comércio - foro privilegiado com jurisdição no litigioso concernente à vida econômica. Resultou daí o anteprojeto redigido em Caracas em 2 de maio de 1785 e endereçado a Gálvez para ser considerado pela Coroa. O que de início se desejava era o impedimento da Justiça Ordinária nas controvérsias mercantis. Questões que envolvessem atos de comércio seriam conhecidas e julgadas pelo Tribunal Consular. Semelhante ente moral, que por delegação régia tinha outorga de serviço público, formava uma jurisdição especial porque nela somente se conheciam causas próprias dos comerciantes. Com a Justiça mercantil mais perto haveria maior rapidez no trâmite processual. A experiência contribuiria, ademais, para a descentralização do Poder Judiciário dos Borbons na América, bem como para seu aperfeiçoamento.

Era o Consulado pessoa jurídica, mescla de direito público e direito privado. Dir-se-ia tratar-se de ente moral de direito "misto" ou "terceiro gênero". Dotado de autonomia governativa, dispunha de tribunal privativo para julgar atos de comércio. Aquinhoado pela Coroa com prerrogativas de gerência do governo econômico "nacional" da Venezuela e investido de poderes jurisdicionais, o Consulado prestava contas apenas ao rei. Deliberando como orgão coletivo delegado e subordinado unicamente ao trono, figurou como expressão popular crioula, irmanando num só Corpo Político agricultores e comerciantes. Sob tais aspectos, e como entidade de fomento da riqueza venezuelana, foi pioneiro na América. Por tais distinções constituiu admiravel corporação de nítida modernidade.

O processo mercantil era contencioso, visto que nele se feria uma discussão entre as partes, culminando por uma decisão que solucionava ou punha fim à contenda. Mas às vezes era administrativo, podendo ser operado "ex-ofício" perante a autoridade e provocado por iniciativa dela. Neste caso o julgamento que nele se pronunciasse não tinha carater executivo nem gerava a "coisa julgada". Sob este aspec-

Rodulfo Corté (Antologia Documental de Venezuela, págs. 124 e segs. Caracas, 1960) e Mercedes (M. Alvarez F.), El Tribunal del Real Consulado de Caracas. Contribucción al estudio de nuestras instituciones, t. II, págs. 71 e segs. Caracas, 1967. 
to o processo era gracioso - opunha-se ao contencioso, dado que não ocorria formação de juizo nem se feria litígio. O processo era sumaríssimo e predominava a oralidade. As causas eram processáveis perante o prior e na presença dos dois cônsules, respectivamente "vogais" dos agricultores e dos comerciantes (92).

O Tribunal Consular de Justiça Mercantil era um órgão de reconciliação e julgamento. Nas demandas cujo valor da causa fosse superior a oitocentos pesos admitia-se recurso para o Tribunal de Alçada, instância de grau superior composta pelo Intendente e por dois comeiciantes livremente escolhidos por ele dentre os dois que cada uma das partes the propunham. Em caso de "injusticia notória" cabia recurso ao "Consejo Supremo de Indias" (93).

Caracas, capital da Venezuela, era a sede do Consulado. O Tribunal de Justiça Mercantil tinha jurisdição em todo o território da Capitania. O Corpo Político consular foi dotado de vastos poderes. Arrebatou ao Capitão General certas faculdades políticas e militares. Despejou a Intendência do governo econômico e subtraiu à Audiência todo contencioso atinente a atos de comércio. Daí os conflitos de jurisdição e competência no começo da atividade consular, prontamente resolvidos pela Coroa em favor da corporação.

Infrações cíveis e criminais eram conhecidas e julgadas pela Real Audiência. O Consulado era competente para o contencioso referente a matéria de direito comercial terrestre ou marítimo dentro do território contido em sua jurisdição. O Tribunal Consular tinha não apenas a faculdade de conhecer e decidir os litígios oriundos de atos de comércio mas, tambem, a de executar as sentenças. Tinha, portanto, a jurisdictio e o imperium. Suas regras eram de direito público e de observância obrigatória - eram normas imperativas (94).

Alem da plena jurisdição e competência em matéria mercantil, o Tribunal Consular foi um protetor da economia venezuelana. Os juizes não eram togados, mas experimentados homens de negócios que operavam no giro comercial e na faina agrícola. Conheciam e julgavam toda controvérsia alusiva a atos de comércio, desde a compra e venda às complexas relações jurídicas concernentes a fretes de navios, avarias, soldos, seguros, naufrágios, parcerias e outras modalidades de figuras ou institutos de direito comercial assinaladas em suas Ordenanças e nas posteriores prescrições régias (95).

(92). — Vide o articulado da referida "Real Cédula de Erección"...

(93). - Ibidem.

(94). - Ibidem.

(95). - Veja-se nossa mencionada tese, O Real Consulado de Caracas..., págs. 226 e segs. 
O Consulado caraqueño foi uma descoberta venezuelana - invento crioulo. A Coroa apenas sancionou o projeto redigido na ambiência das motivações da Capitania. A Real Cédula de 3 de junho de 1792 consubstanciou seu fundamento legal. Atuou como Tribunal de Justiça Mercantil e como Junta de Comércio - dois orgãos distintos que compunham o Corpo Consular. O objeto social da Junta foi o fomento da economia - agricultura e vias de comunicação - apurada no decurso de 1793 a 1810 , que comprova a crescente humanização da paisagem das terras e águas da Capitania (96).

Duzentos e cinquenta e quatro registros de "comércio livre" confirmam a intensidade do tráfico. As proeminências acham-se na disposição percentual dos navios que operavam no giro entre Venezuela e Espanha naquele período: 120 bergantins (47\%), 59 fragatas (23\%), 48 polacras $(19 \%), 13$ goletas $(5 \%), 9$ paquebotes $(4 \%)$ e 5 saetías $(2 \%)$. La Guaira e Cadiz eram os polos de desenvolvimento do tráfico entre a colônia e o reino: La Guaira com $94,3 \%$ em relação ao total dos portos venezuelanos e Cadiz com $86 \%$ do movimento dos portos peninsulares. $O$ valor das carregações da Capitania atesta a distribuição percentual: de 591.994.498 reales de vellon, sairam por $\mathrm{La}$ Guaira, 548.306.061 rs.v., sendo desembarcados em Cadiz ...... 508.820.718 rs.v. O restante distribuiu-se pelos demais portos venezuelanos: Cumaná 18.839.463 rs.v. (3,2\%), Maracaibo .... $14.215 .314(2,4 \%)$ e Guayana 633.660 rs.v. $(0,1 \%)$. E pelos portos espanhois da maneira seguinte: Barcelona 23.140 .628 rs.v. $(5,8 \%)$, Santander $32.121 .508(5,4 \%)$, La Coruña 9.108.601 $(1,5 \%)$, Malaga $6.411 .880(1,1 \%)$, Alicante $1.785 .165(0,3 \%)$ e Cartagena 595.998 rs.v. $(0,1 \%)$. Os algarismos comprovam as preeminências de La Guaira e Cadiz em relação aos respectivos totais dos portos venezuelanos e espanhois (97).

Ressaltam os percentuais dos gêneros exportados: cacau $(62,2 \%)$, anil $(20,9 \%)$, tabaco $(10,3 \%)$ algodão $(2,8 \%)$, café $(1,6)$, couros $(0,8 \%)$, açúcar $(0,7 \%)$ e prata $(0,3 \%)$, ficando os 0,4 restantes com os demais produtos que figuram nos "legajos" da pauta da exportação venezuelana (98).

Toda política econômica consular atendeu a um "plano diretor" que previa investimentos nos setores da produção e da circulação da riqueza colonial. Daí a execução dum programa de modernização da infra-estrutura de transportes, comunicações saneamento básico e uti-

(96). -.Idem, págs. 265 e segs.

(97). - Apuração realizada com os elementos extraidos do "Archivo General de Indias". Indiferente General, legajos n\%s. 2453 a 2461 . Veja-se ainda nossa citada tese - $O$ Real Consulado, págs. 285 e segs.; 336 e segs.

(98). - Ibidem. 
lização mais racional dos recursos naturais da Capitania. A relevância dos problemas de fomento da economia fez que a Junta Consular estabelecesse no quadro das metas prioritárias uma programação para a assistência financeira aos lavradores crioulos e para obras de infraestrutura - abertura e conservação de estradas. Para isso o Consulado dispunha de recursos próprios, constituindo-se a sua receita da "averia" e de muitas oriundas do contencioso concernente a atos de comércio. Graças a isso pôde atender ao seu objeto social, acentuando o intercâmbio intrazonal e a ocupação econômica de vazios demográficos até então isolados entre si (99).

Pelo que realizou, o Consulado de Caracas foi uma entidade moral dinâmica e empreendedora. Sua política de integração das macroregiões, pelos investimentos no setor da infra-estrutura, possibilitou melhores condições de poupança social. Pela união dos portos marítimos aos vales agricultados da hinterlândia, através da abertura e conservação de estradas, sobretudo da via Caracas-La Guaira, importante elo de polos de desenvolvimento da economia venezuelana, foi fator da humanização da paisagem e da mudança estrutural, condição imprescindível à emancipação política da Venezuela ordenada a partir de 1810 (100).

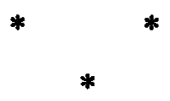

MANUEL NUNES DIAS. - Nasceu em São Paulo aos 31 de maio de 1921. Estudou História, Geografia, Direito e Economia na Universidade de São Paulo, bacharelando-se em Jornalismo pela Pontifícia Universidade Católica de São Paulo, onde fez jus ao prêmio "Souza Filho", dado ao aluno classificado em primeiro lugar no decorrer do Curso.

Autor de algumas dezenas de trabalhos do mais alto valor cultural e científico, publicados no País e no estrangeiro, fez toda a carreira docente universitária na Universidade de São Paulo doutoramento, livre-docência e cátedra - com distinção e louvor, dedicando-se desde 1952, no Departamento de História da Faculdade de Filosofia da Universidade de São Paulo, ao ensino e à pesquisa no âmbito da História das Instituições Econômicas.

Dos seus trabalhos publicados destacam-se, sobretudo, suas teses seguintes: $O$ Capitalismo Moderno (1415-1545) — editada em dois alentados volumes pela Universidade de Coimbra; $A$

(99). - Ibidem.

(100). - Veja-se nossa referida comunicação, apresentada ao $4^{\circ}$ Congresso Internacional de História da América - El Real Consulado de Caracas, factor economico de la Independência de Venezuela, in tomo VI, 287 a 298. Buenos Aires, 1966. 
Companhia Geral do Grão Pará e Maranhão (1755-1778) - eđitada em dois volumes pela Universidade Federal do Pará e, num grosso volume, em São Paulo, pela Revista de História; $O{ }^{\text {"Co- }}$ mércio livre" entre Havana e os portos da Espanha (1788-1810) - editado em São Paulo, em dois volumes; $O$ real Consulado de Caracas (1793-1810) - publicada em Caracas, num grosso volume, pela Academia Nacional de História.

Membro de três Academias de História - Academia Portuguesa da História, Academia Paulista de História e Academia Nacional da História (Venezuela) - é ainda vogal do Centro de Estudos Históricos Ultramarinos (Lisboa), pertencendo, outrossim, a outras entidades culturais e cientificas nacionais e estrangei as.

Participou de diversos Congressos, Simpósios e Colóquios, com comunicações, na Europa, na América e na Äfrica, continentes em que pesquisou largo tempo, nos Arquivos Públícos e particulares, permitindo-lhe reunir precioso acervo científico para elaboração de seus trabalhos no âmbito da Economia Atlântica e no setor da História das Instituiçōes Econômicas.

Foi chefe do Departamento de História da Faculdade de Filosofia, de onde saiu por ter sido nomeado Diretor da Escola de Comunicações e Artes da Universidade de São Paulo, onde ainda se encontra.

Orientador de dissertações de mestrado e teses de doutoramento, vem fazendo "Escola" tendo em vista o despertar de gosto e tendências para o estudo da História das Instituições Econômicas.

Foi recentemente eleito coordenador do Projeto de publicação da História Geral da América, patrocinado pela OEA, operando com cientistas nacionais e estrangeiros da mais alta qualificação profissional, cultural e científica. 